\title{
Cationic Palladium(II)-Catalyzed Addition of Arylboronic Acids to Nitriles. One Step Synthesis of Benzofurans from Phenoxyacetonitriles
}

\author{
Baowei Zhao and Xiyan Lu*
}

State Key Laboratory of Organometallic Chemistry, Shanghai Institute of Organic

Chemistry, Chinese Academyof Sciences, 354 Fenglin Lu, Shanghai 200032, China

E-mail: xylu@mail.sioc.ac.cn

\section{Supporting Information (2)}

\section{Copies of ${ }^{1}{ }^{H}$ NMR and ${ }^{13}$ C NMR spectra:}

\begin{tabular}{|c|c|}
\hline${ }^{1}$ H NMR of cat. B & $\mathrm{S} 1$ \\
\hline${ }^{1}$ H NMR of cat. C & $\mathrm{S} 2$ \\
\hline Compound 5aa & S3-S4 \\
\hline Compound 5ba & S5-S6 \\
\hline Compound $6 \mathbf{b a}$ & S7-S8 \\
\hline Compound $\mathbf{5 f a}$ & S9-S11 \\
\hline Compound $\mathbf{6 f a}$ & S12-S14 \\
\hline Compound 5ga & S15-S16 \\
\hline Compound 5ha & S17-S19 \\
\hline Compound 6ha & S20-S22 \\
\hline Compound 8 & S23-S24 \\
\hline Compound $\mathbf{4 b}$ & S25-S26 \\
\hline Compound 5ab & S27-S28 \\
\hline Compound 5bb & S29-S30 \\
\hline Compound $\mathbf{6 b b}$ & S31-S32 \\
\hline Compound 5cb & S33-S34 \\
\hline Compound 5db & S35-S36 \\
\hline Compound 6db & S37-S38 \\
\hline Compound 5eb & S39-S40 \\
\hline Compound $\mathbf{5 f b}$ & S41-S43 \\
\hline Compound 5gb & S44-S45 \\
\hline Compound 5hb & S46-S48 \\
\hline Compound 5ib & S49-S51 \\
\hline Compound $\mathbf{5 j b}$ & S52-S53 \\
\hline Compound 5kb & S54-S55 \\
\hline Compound 5lb & S56-S57 \\
\hline Compound 6lb & S58-S59 \\
\hline
\end{tabular}




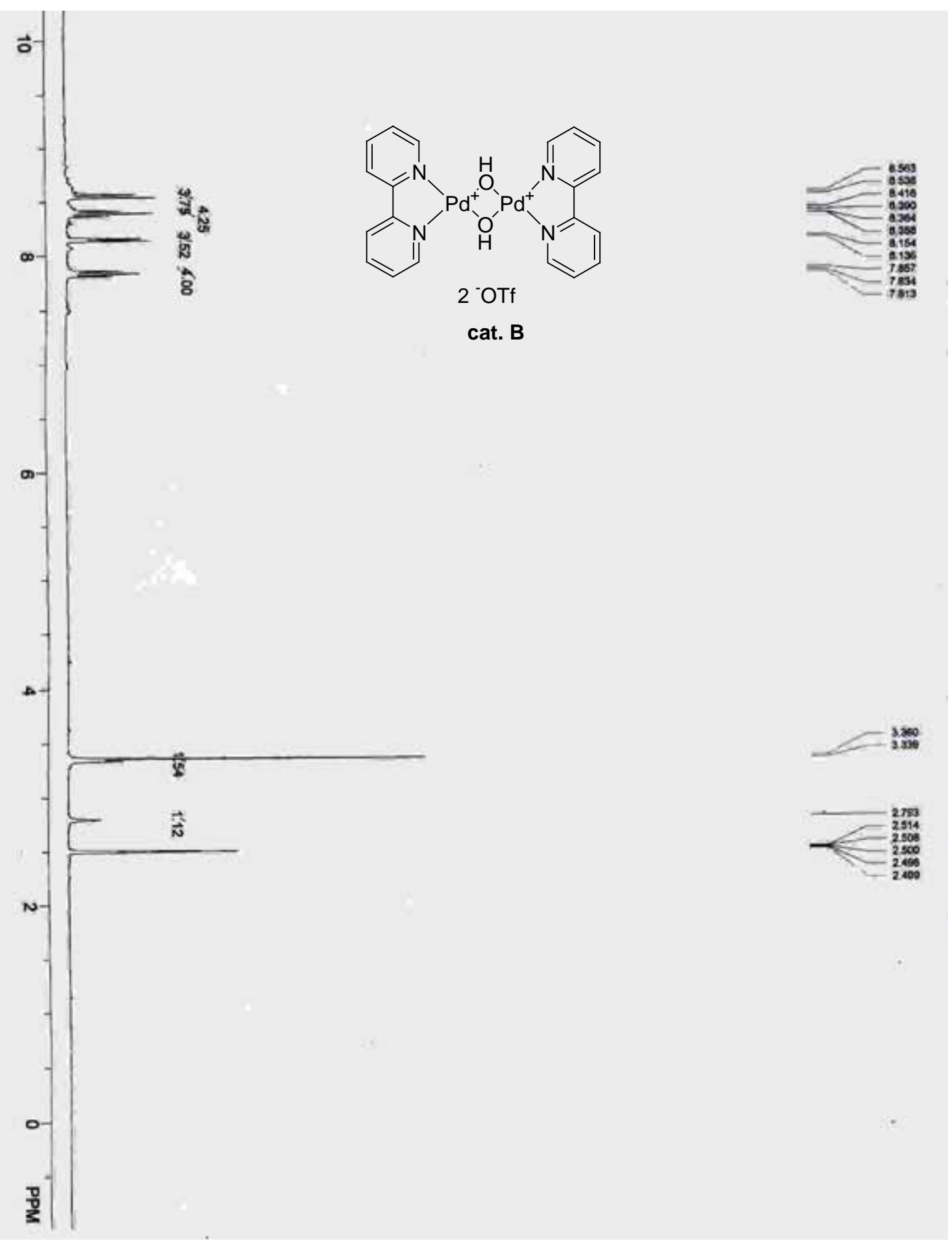



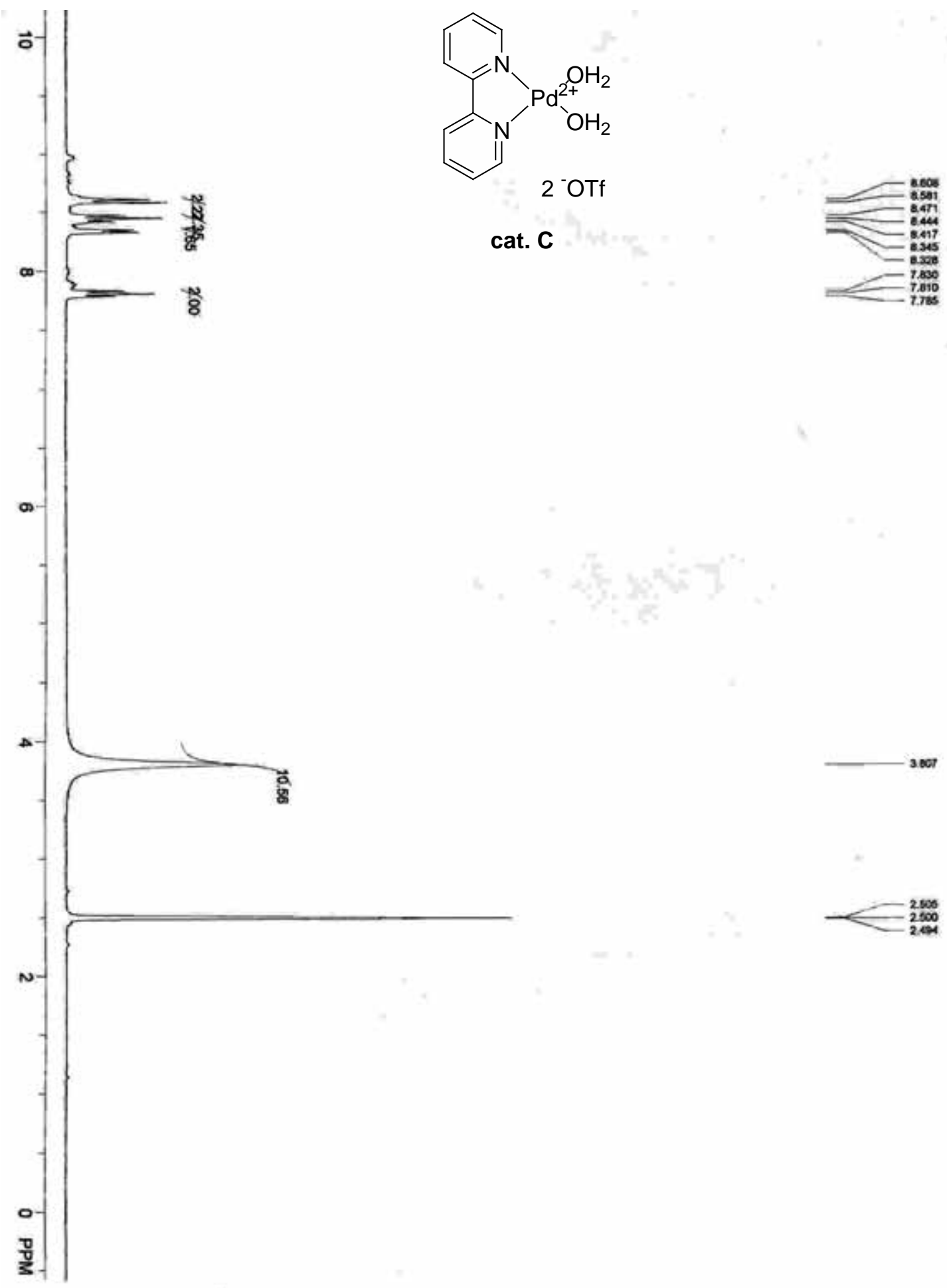


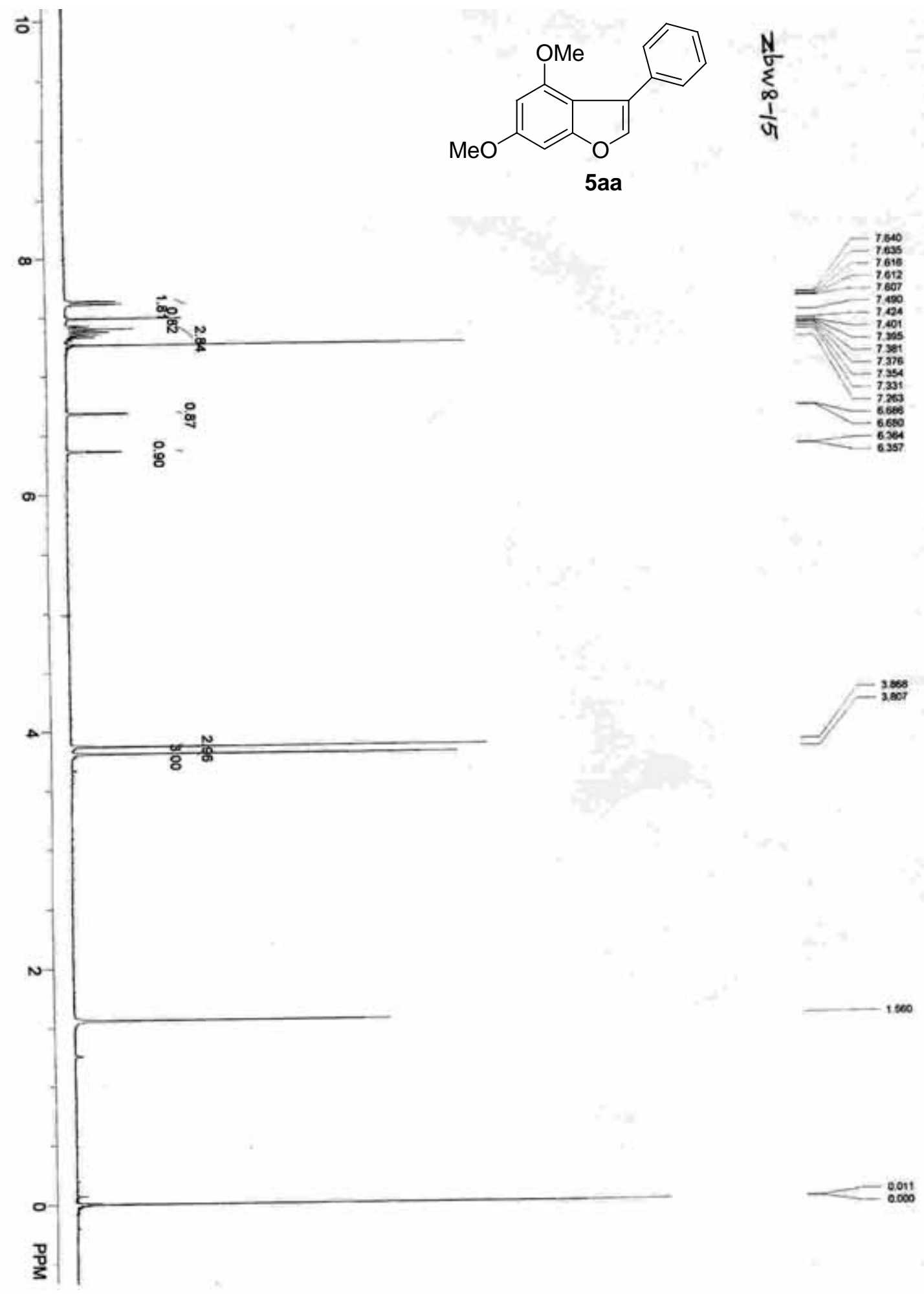




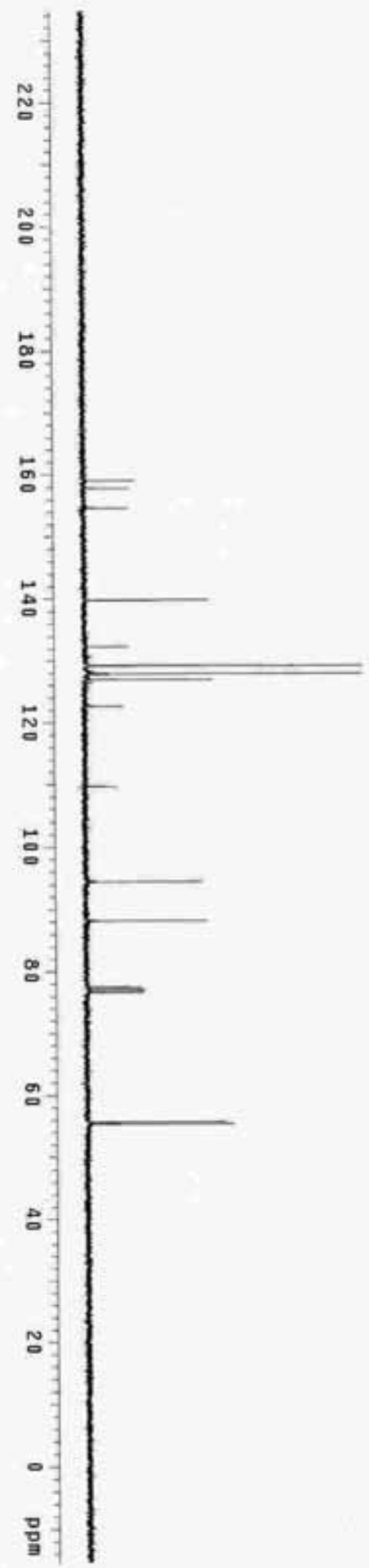

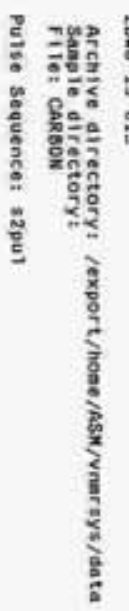

157.78
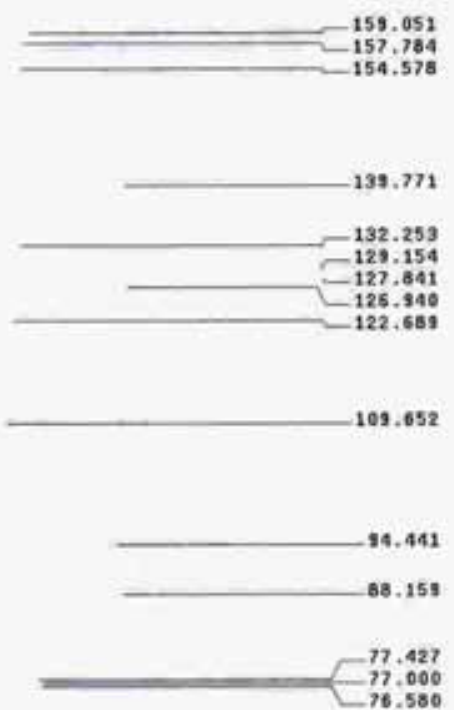

55.56

$-77.000$ 


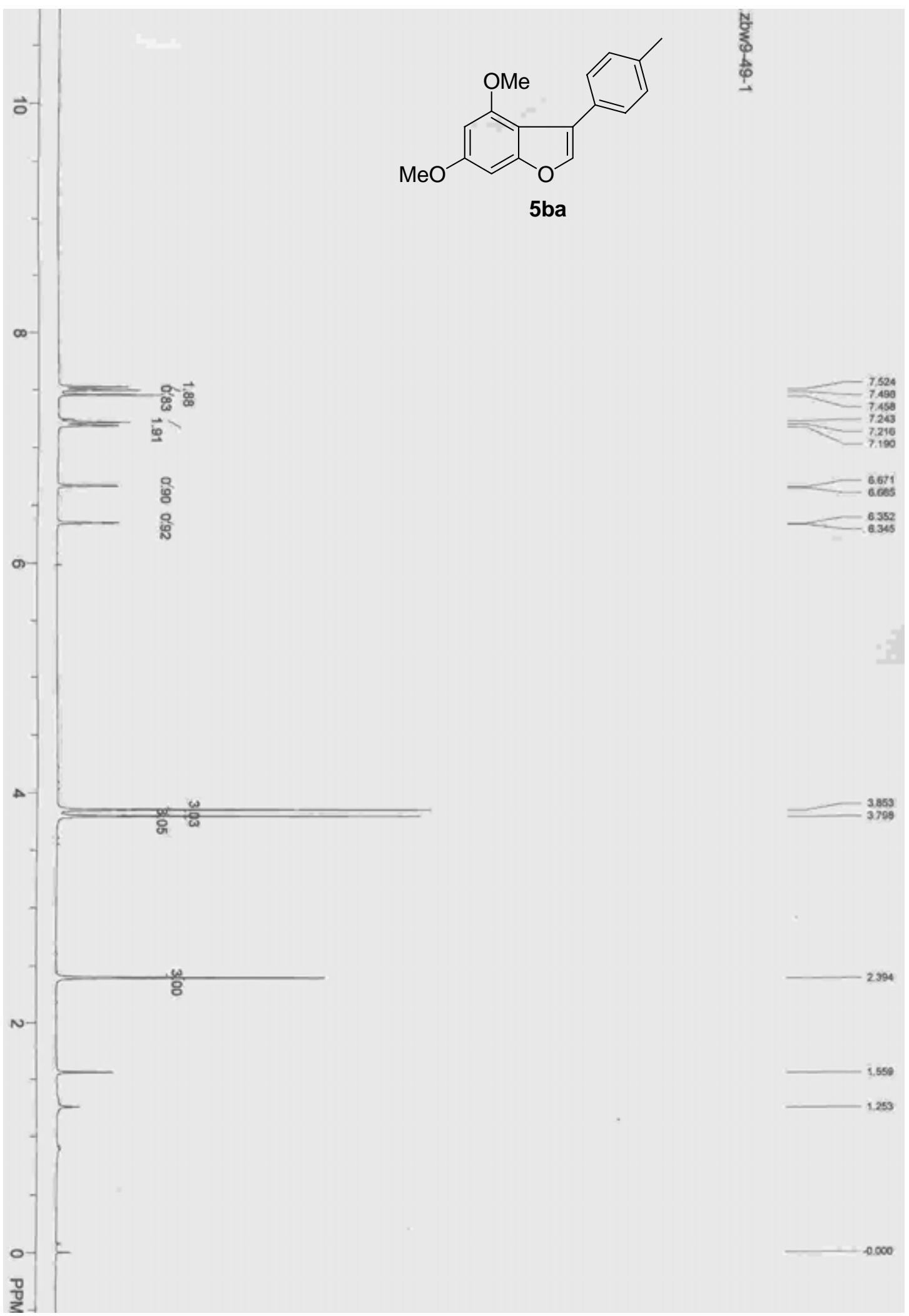



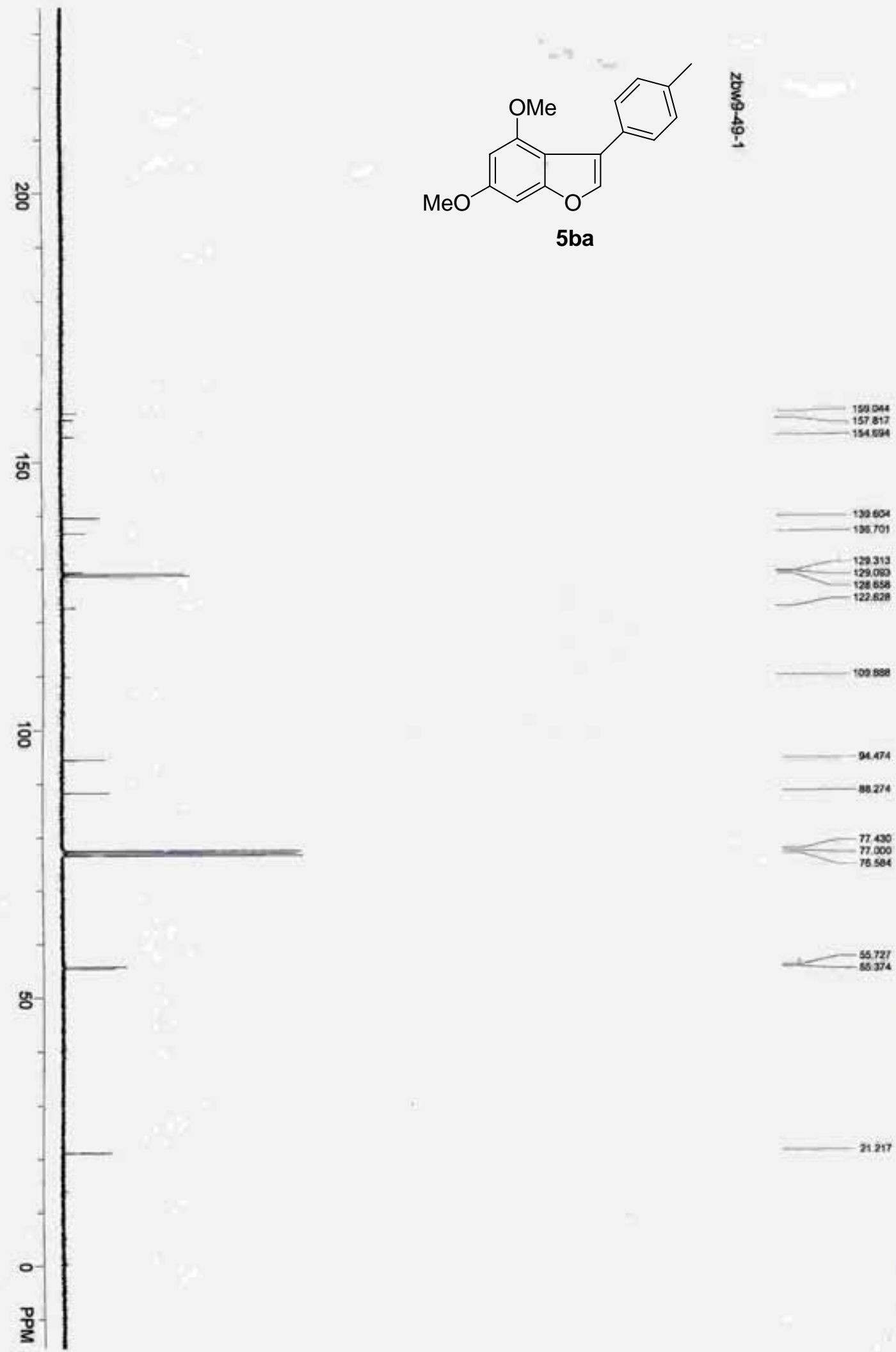

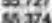

21 2 


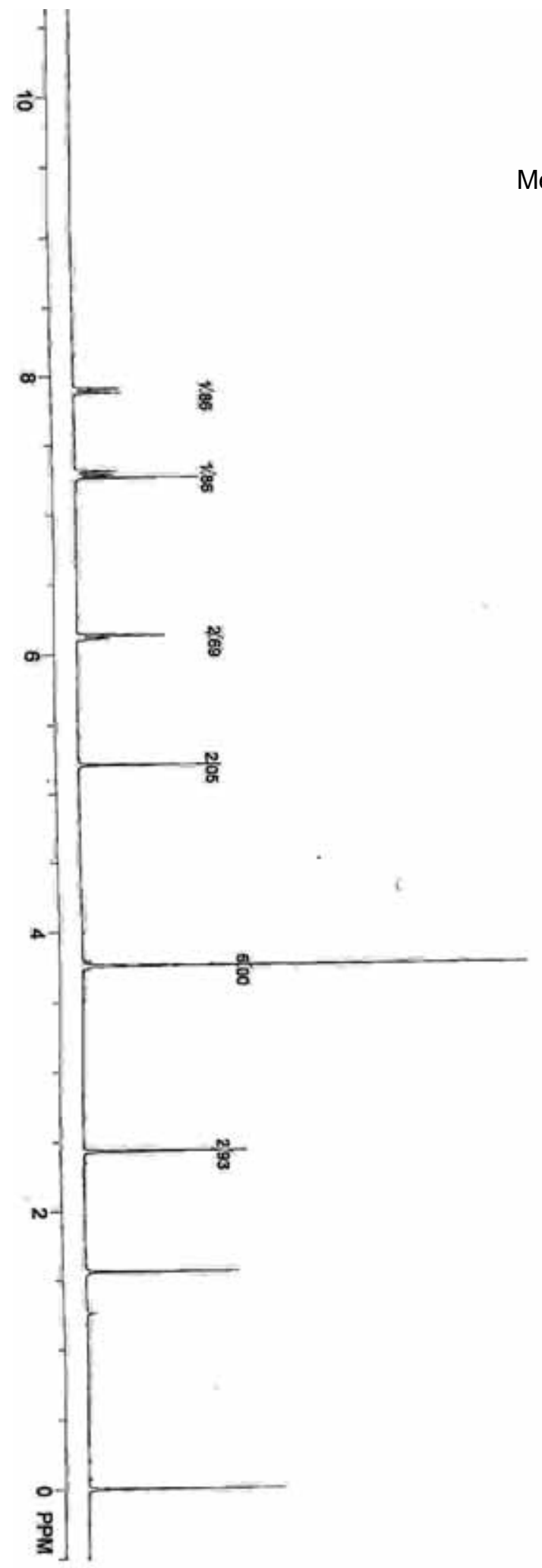<smiles>COc1cc(OC)cc(OCC(=O)c2ccc(C)cc2)c1</smiles>
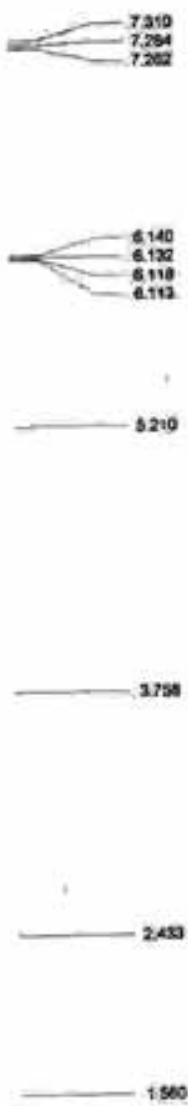

0.000 

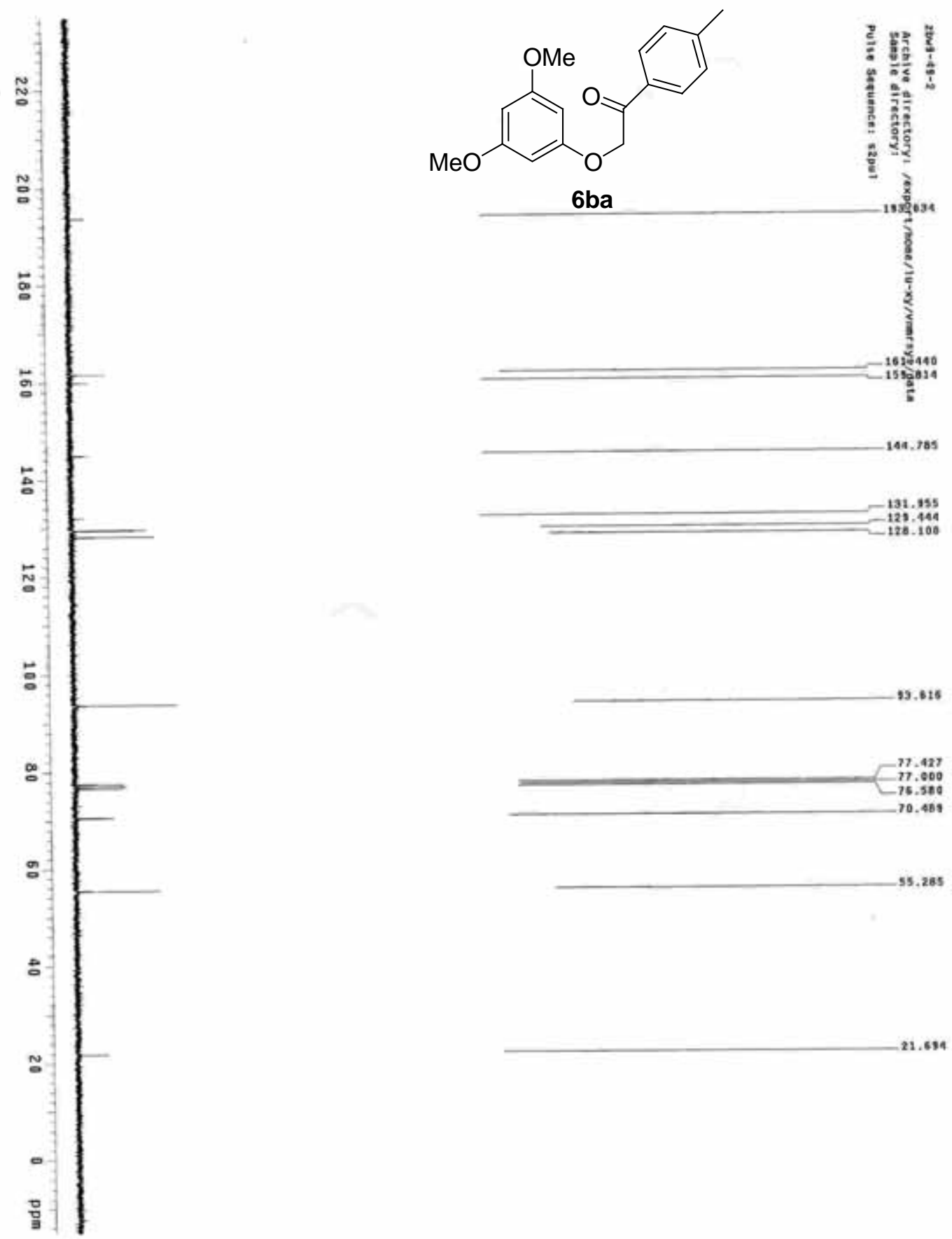

131.135
121.494

.816

77.427
77.000
75.580

5. 285

21.634 


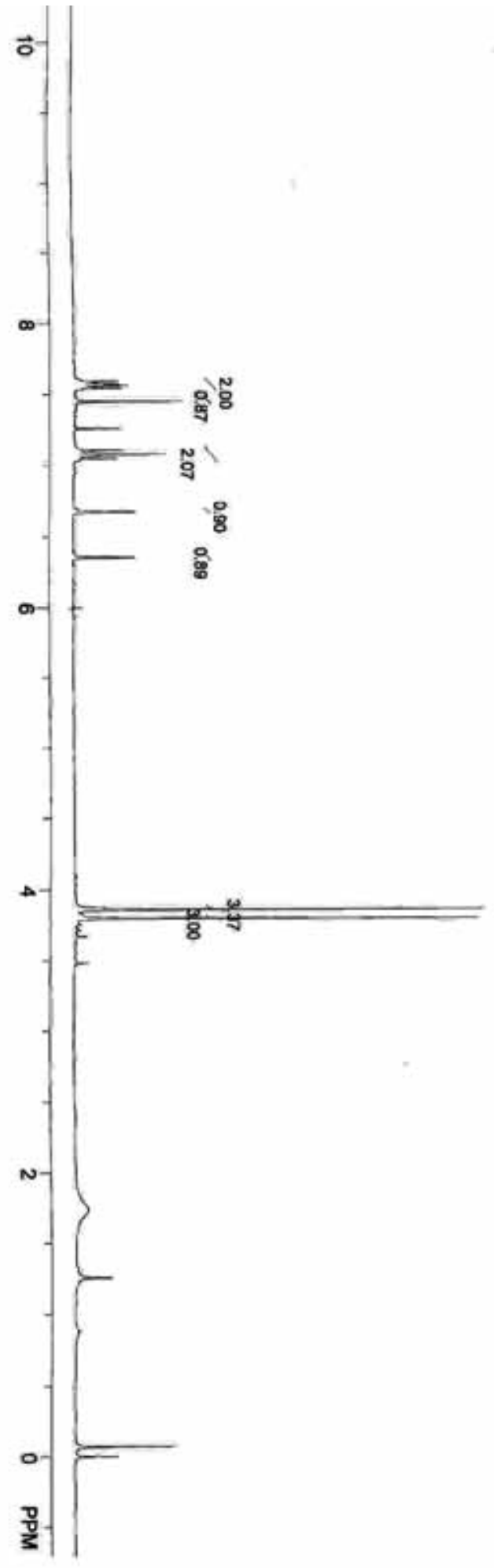<smiles>COc1cc(OC)c2c(-c3ccc(F)cc3)coc2c1</smiles>

$5 f a$
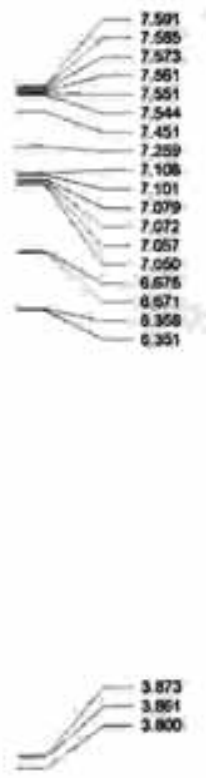

$-0002$ 


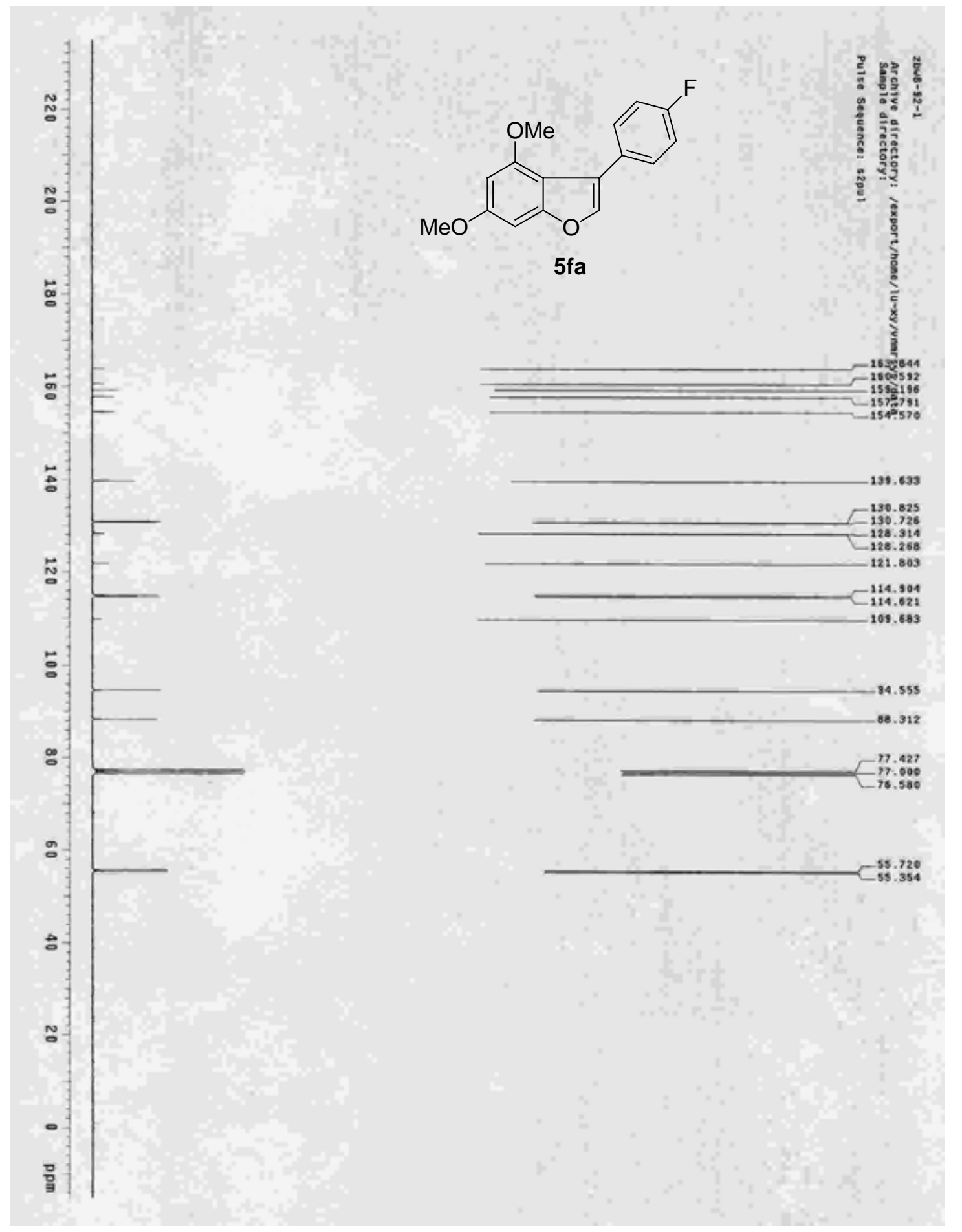




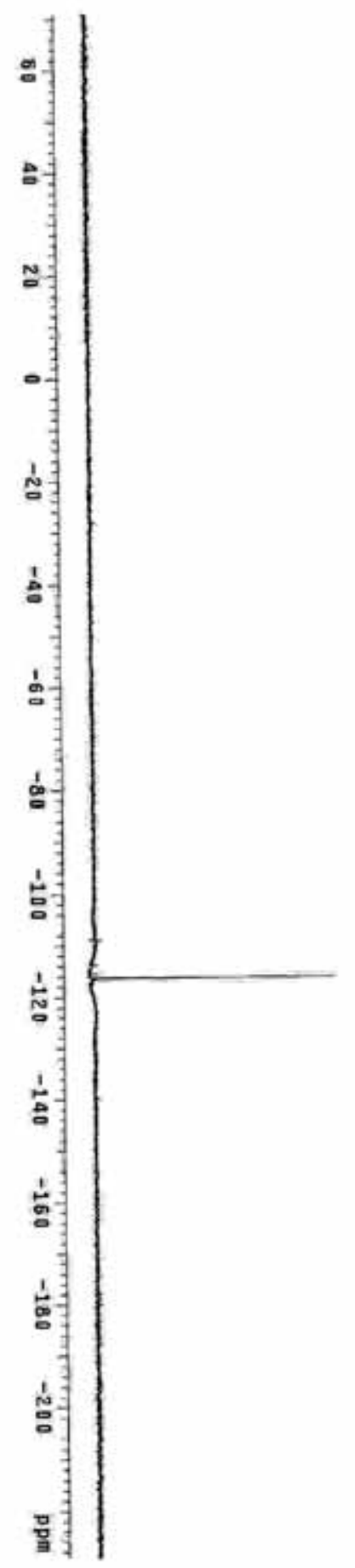

$5 f a$

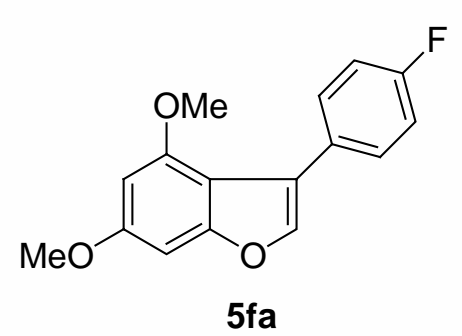

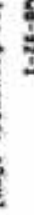




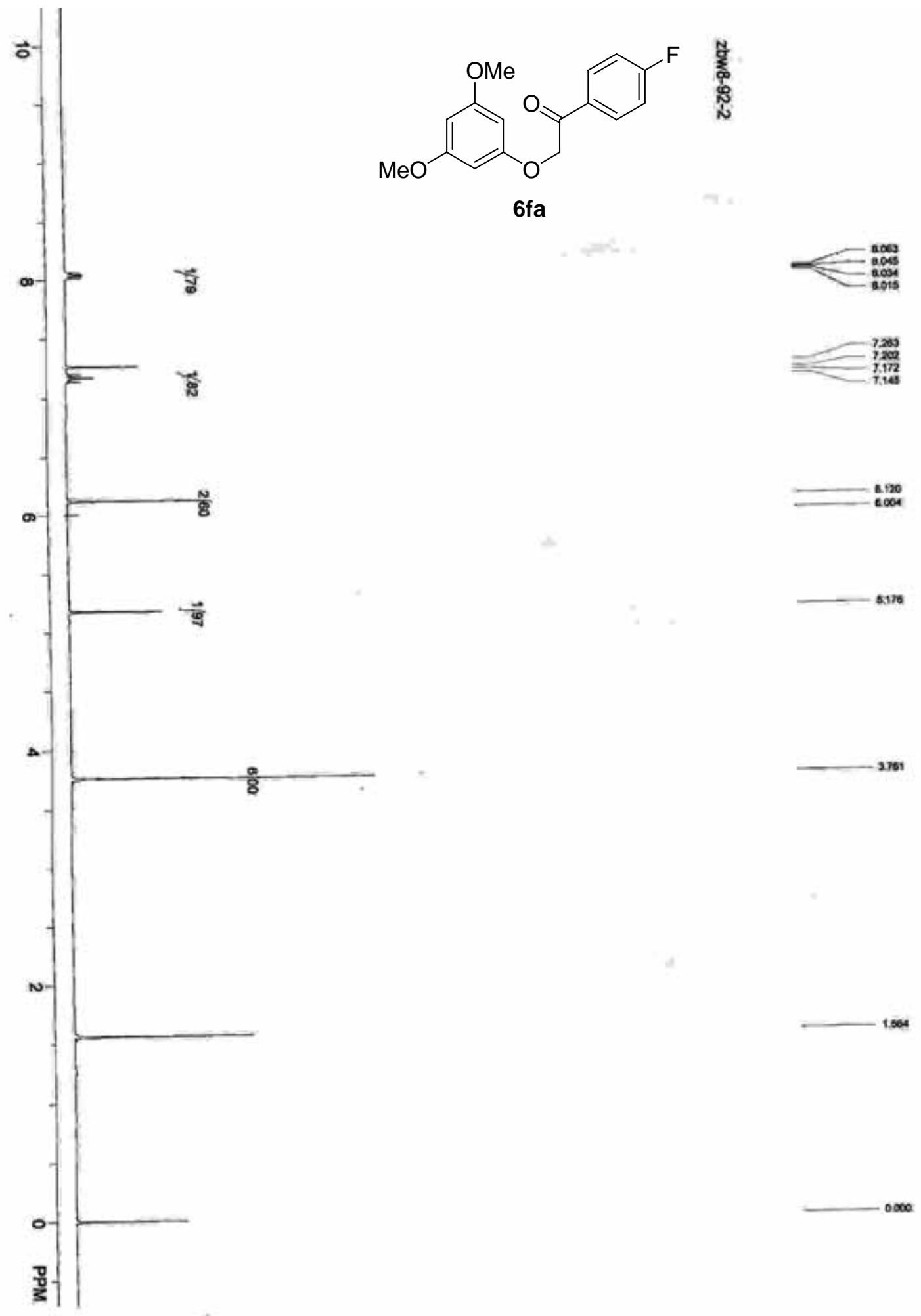



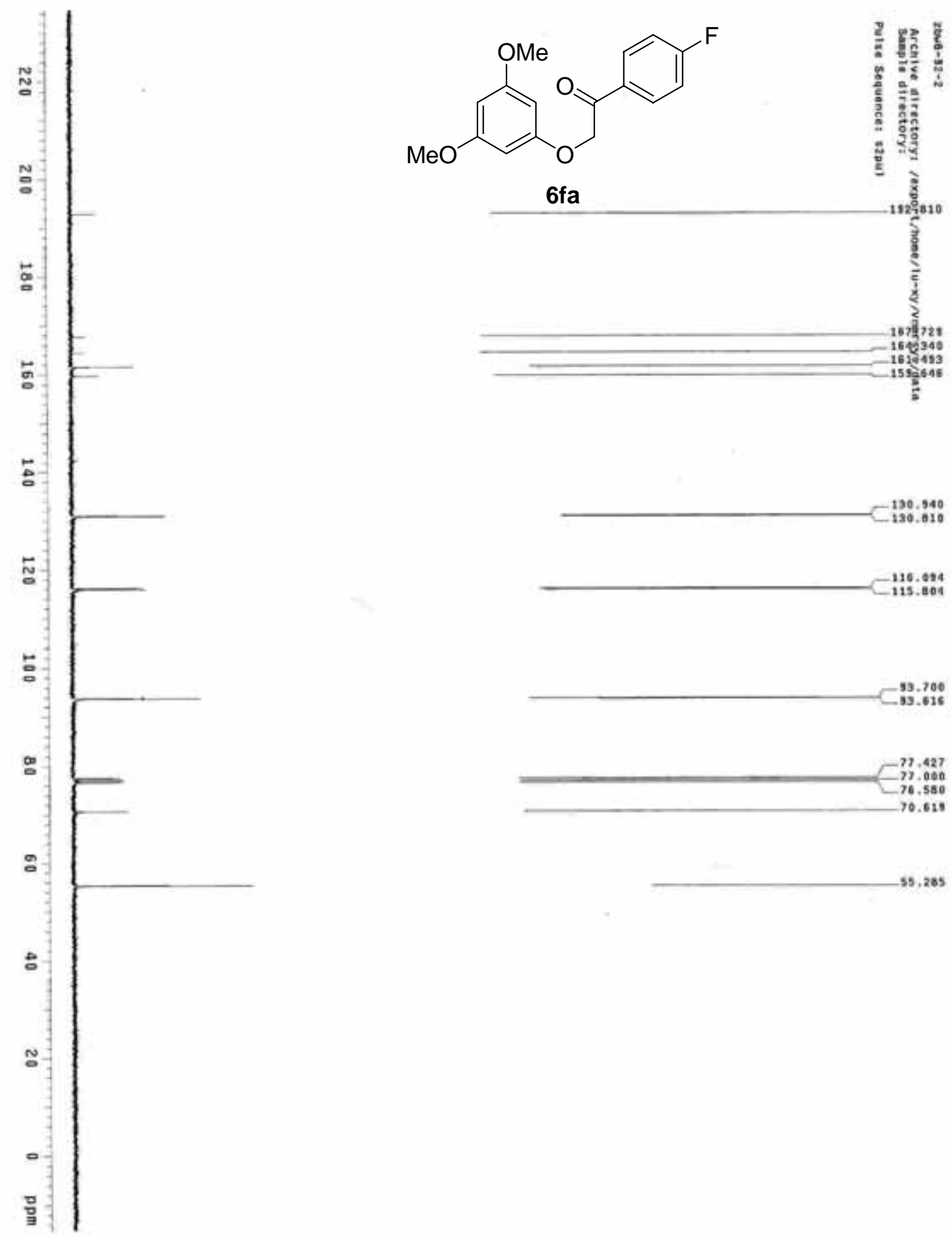

-130.940
-130.910

-116.024
-115.804

-93.700
-39.635

$-71.427$

$-76.580$

$-55,285$ 


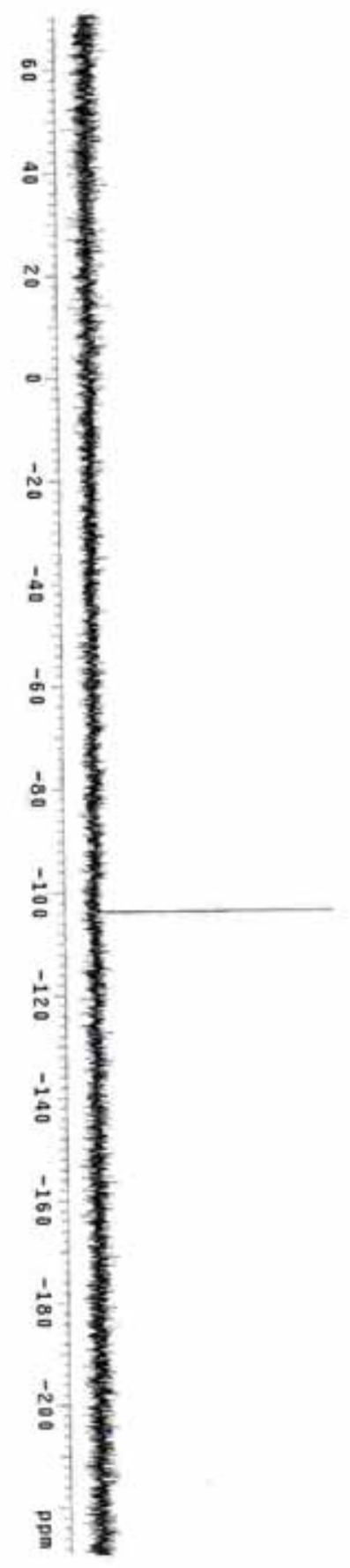




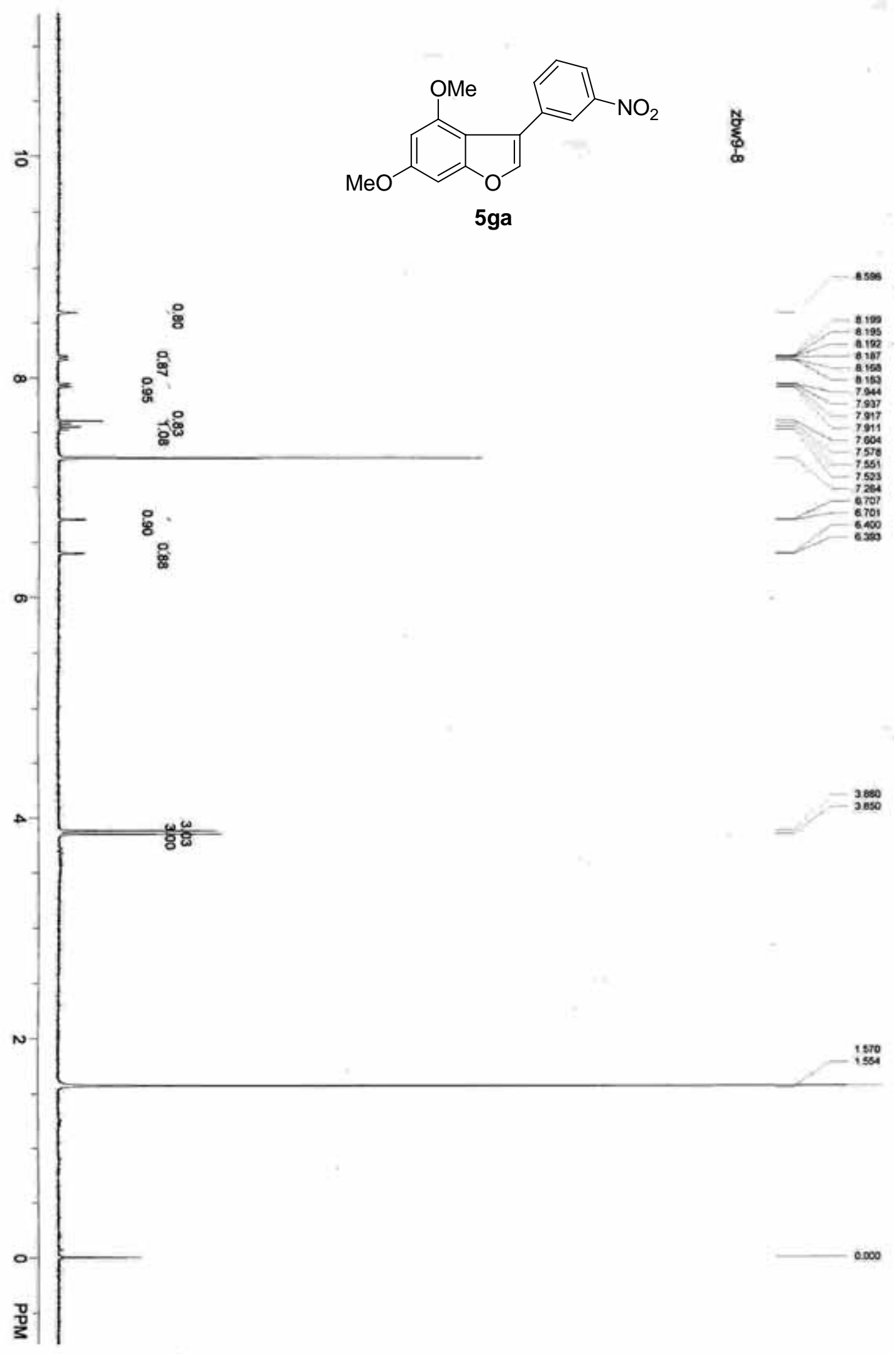



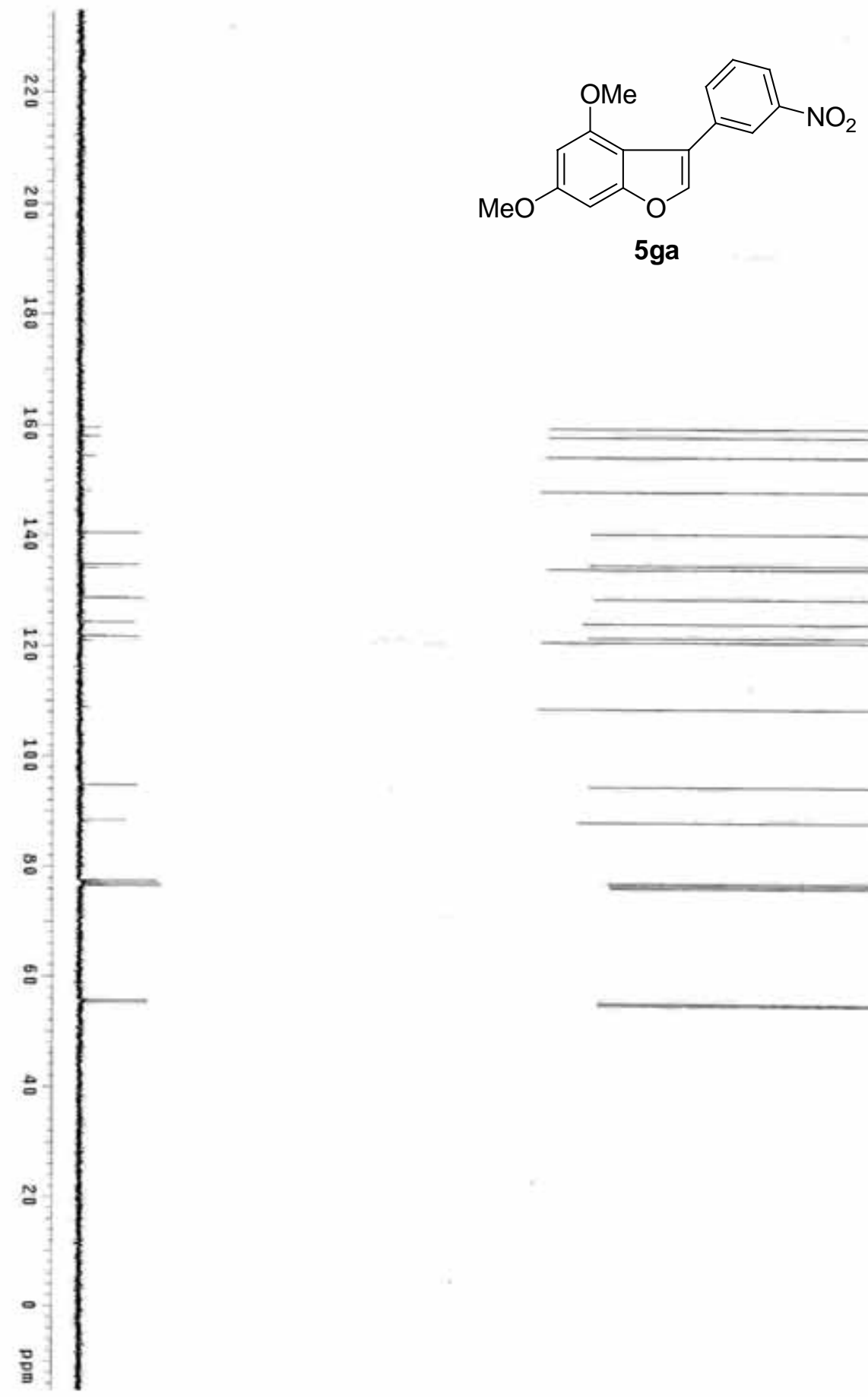

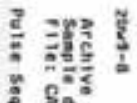

$5 g a$

140.442

$-134.709$

$-121.712$

108.904

34.798

86.3s?

77.420

-77.0200
-75.573

55.720
-55.277 


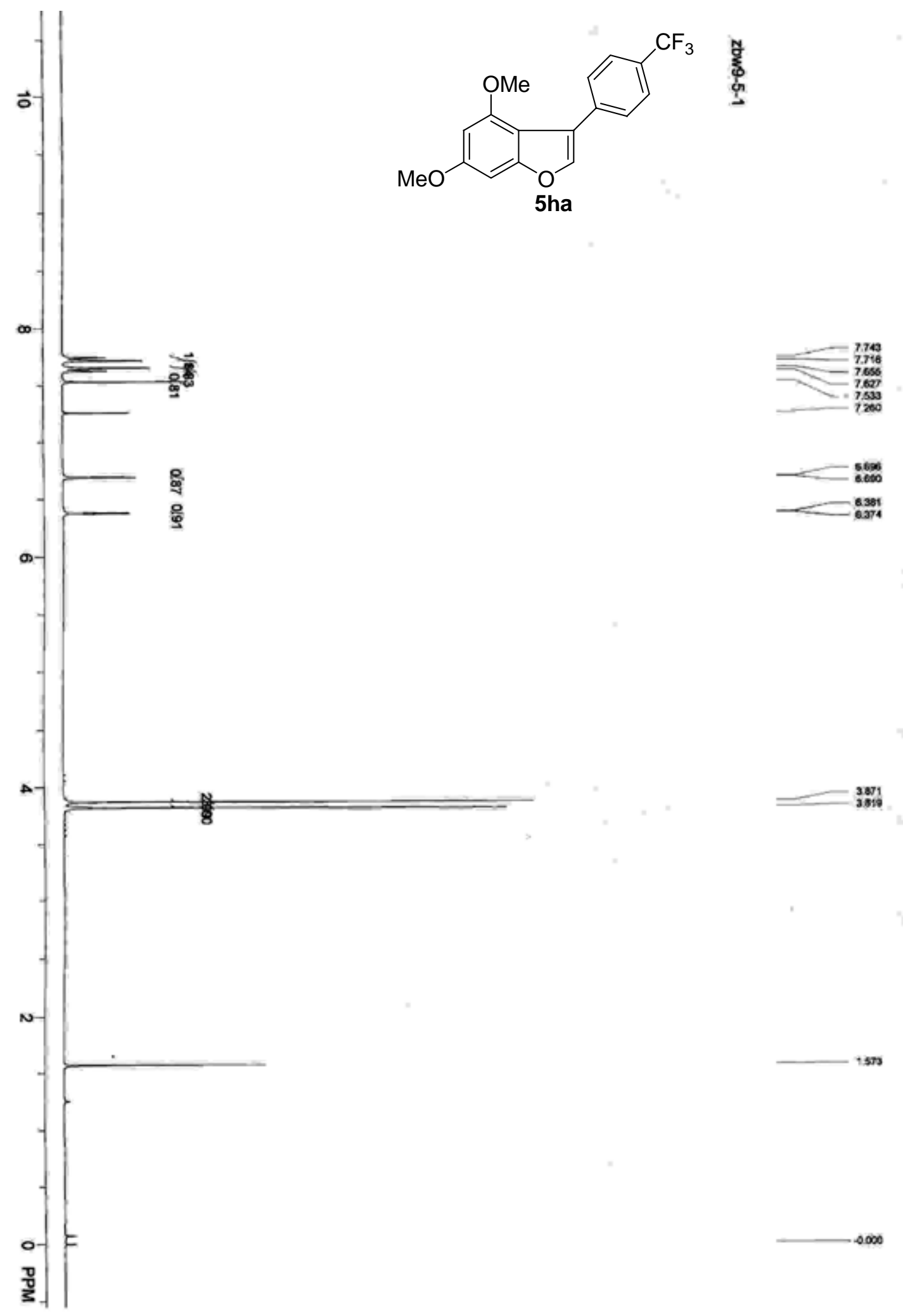



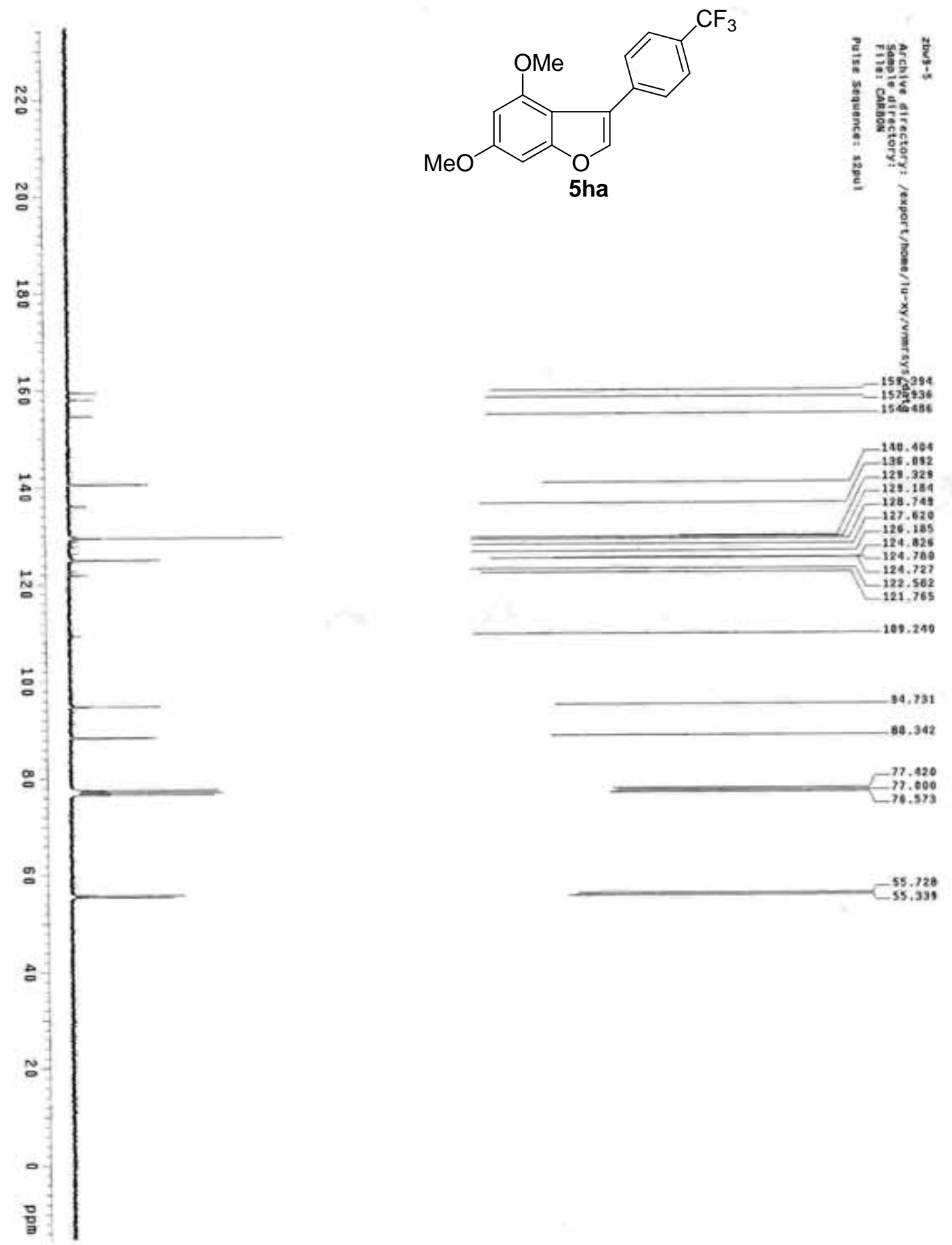

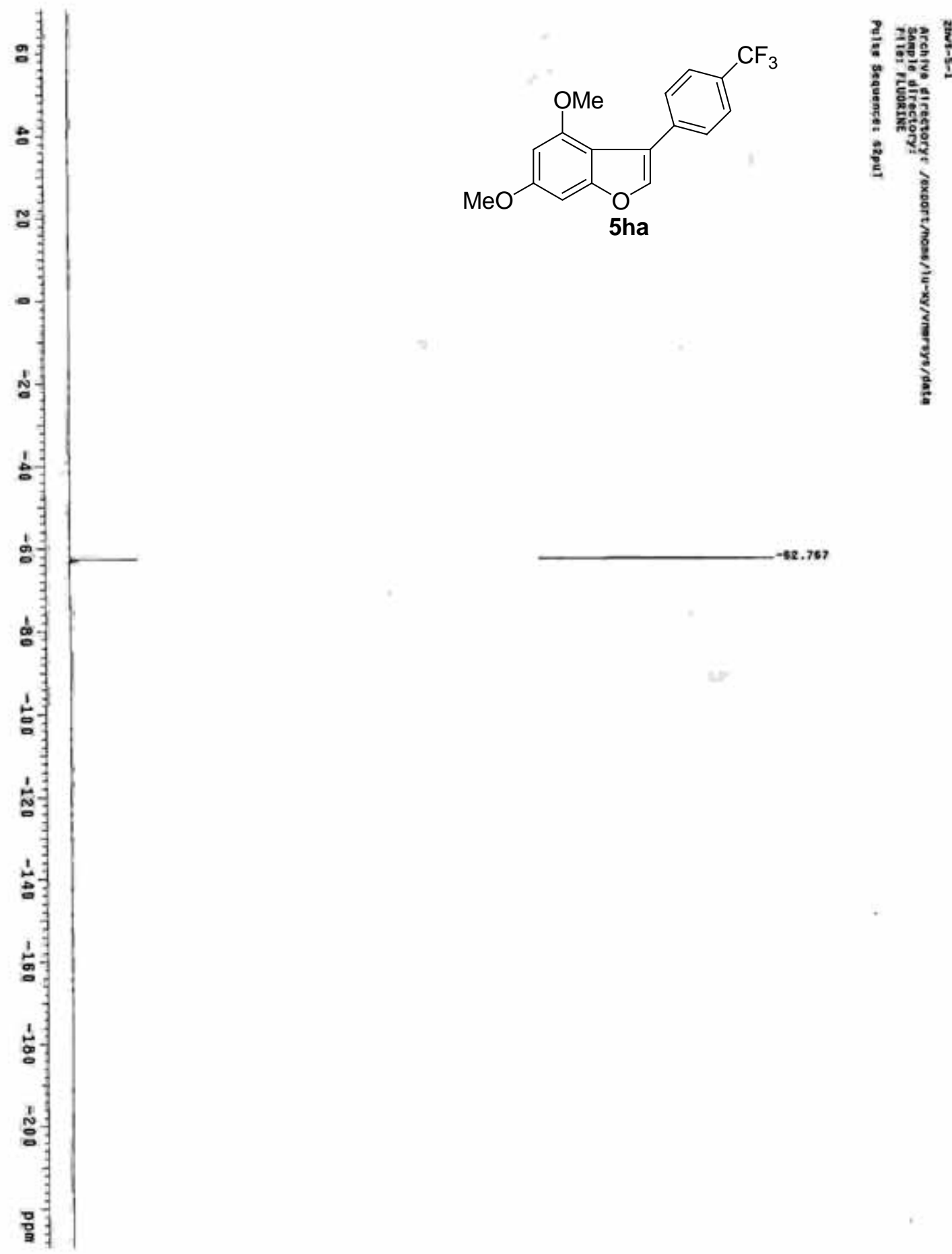


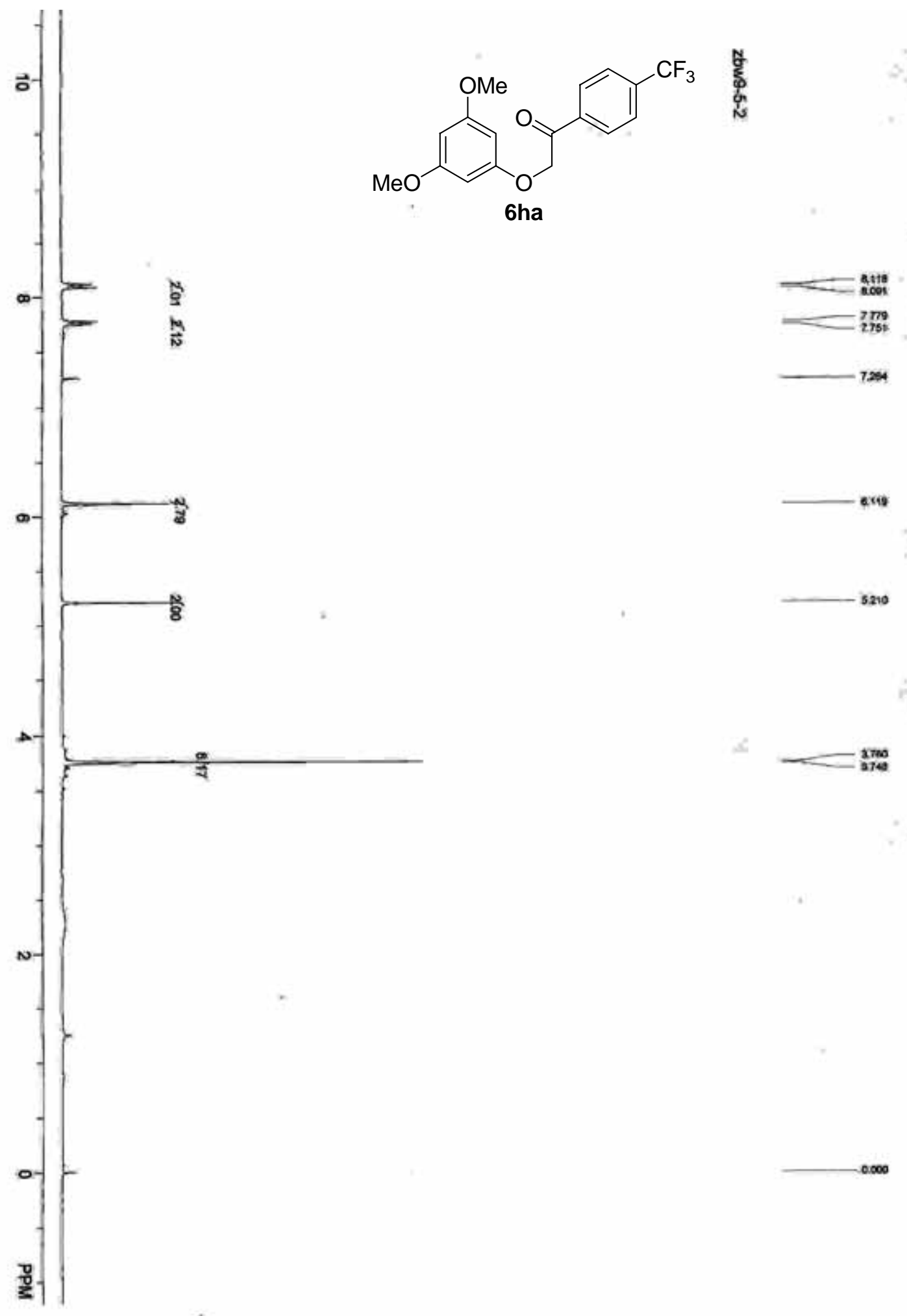




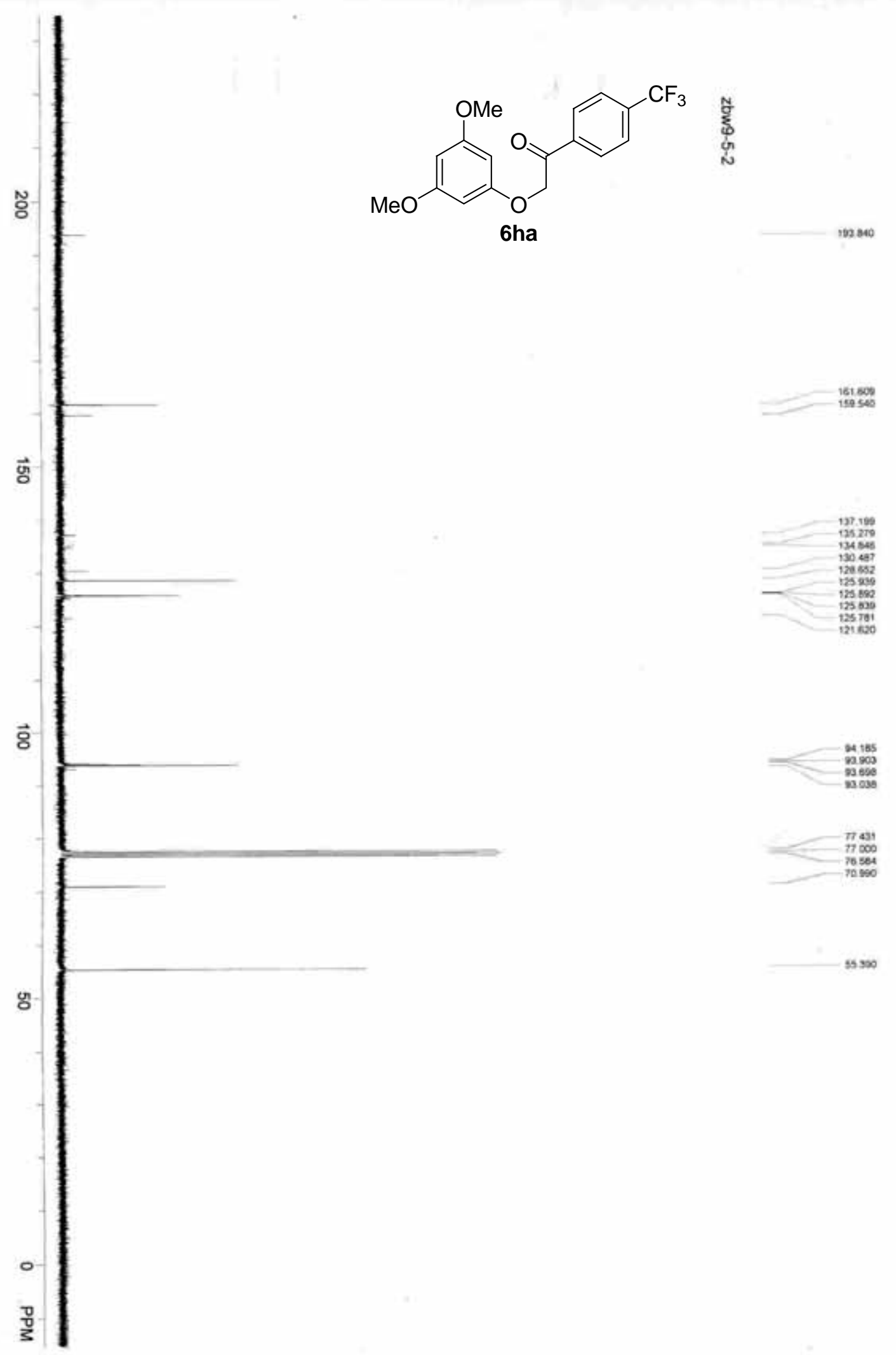



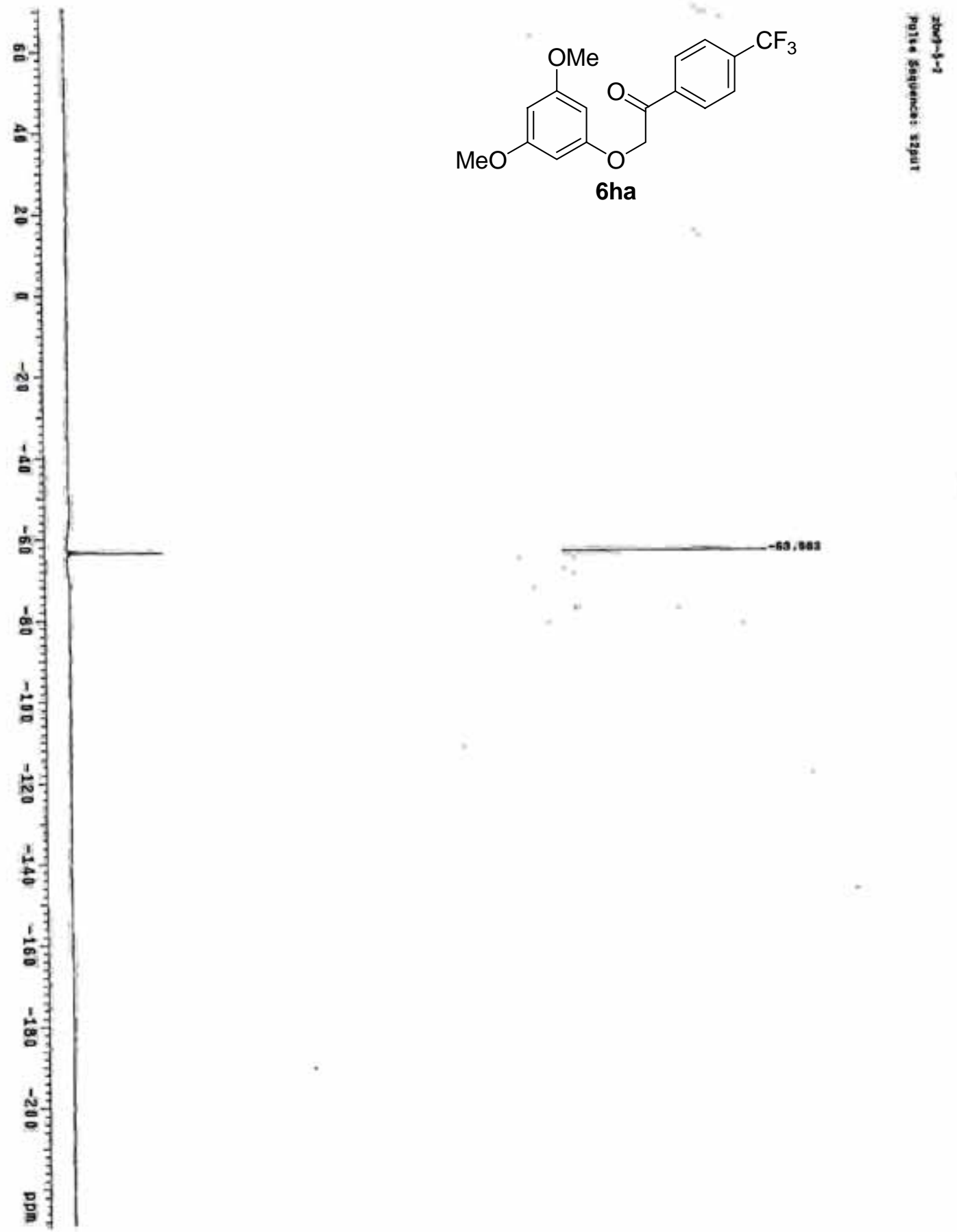


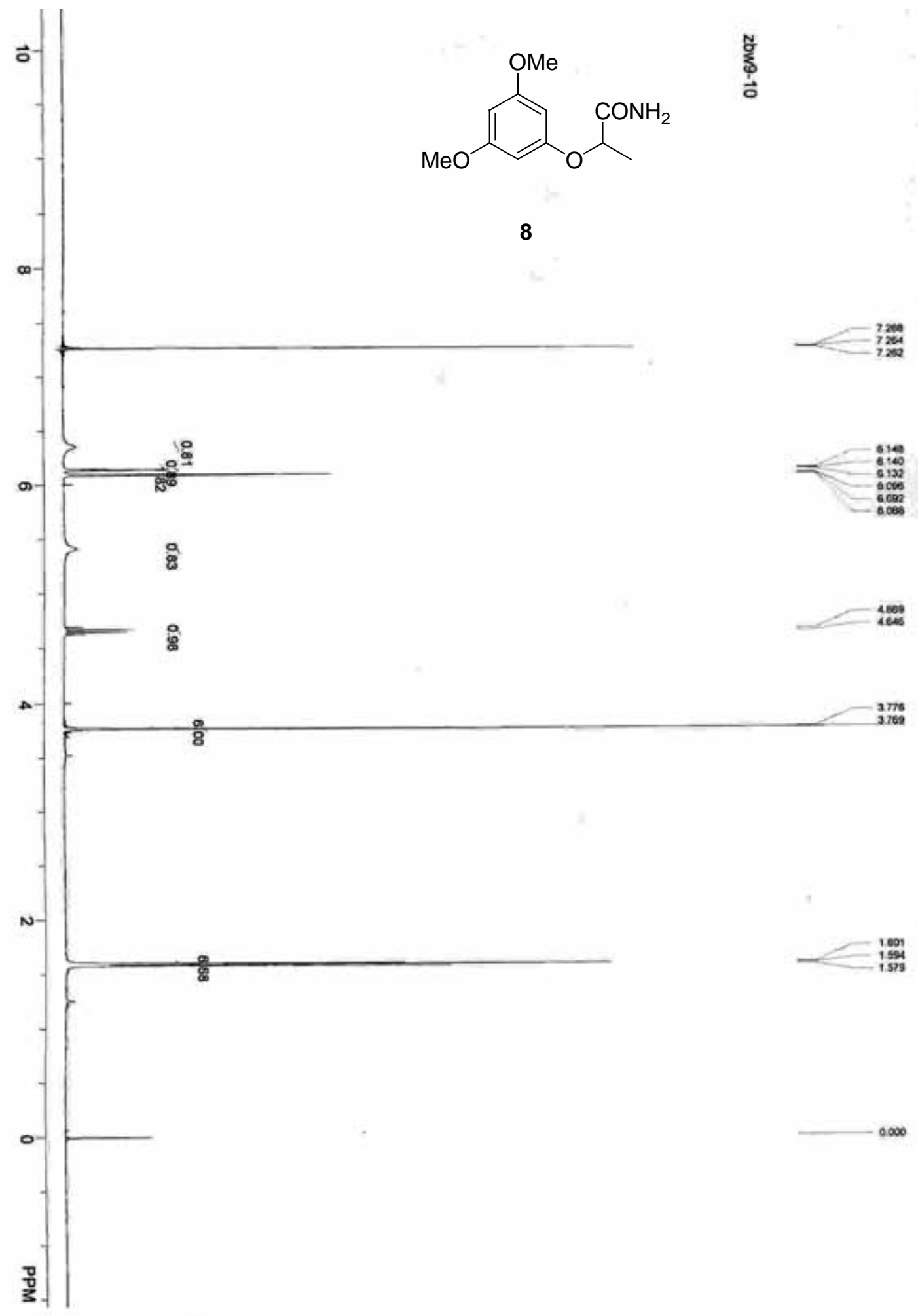



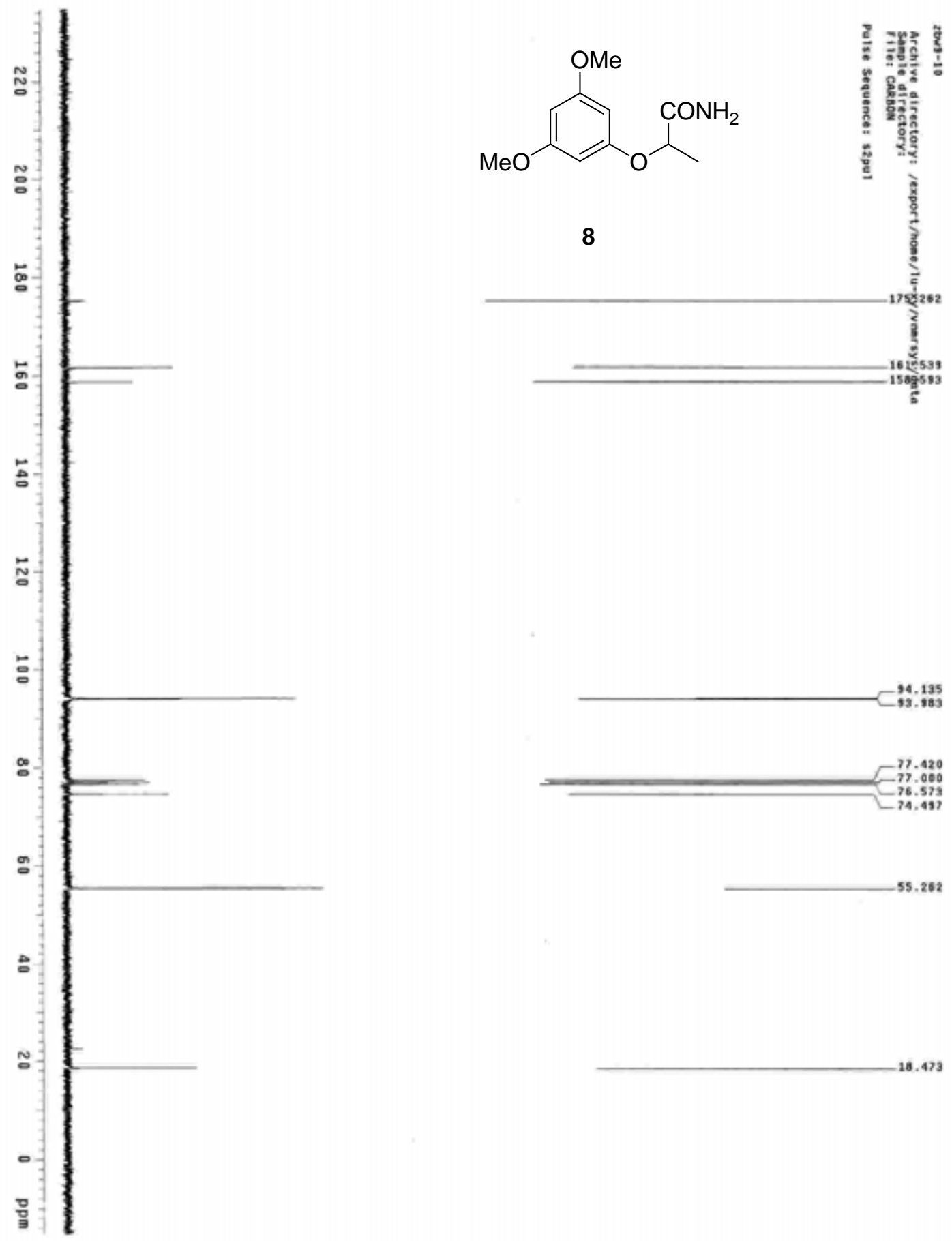

9., 195

77.420
-71.000
-76.53

-76.573
-74.49

55.262

18. 473 

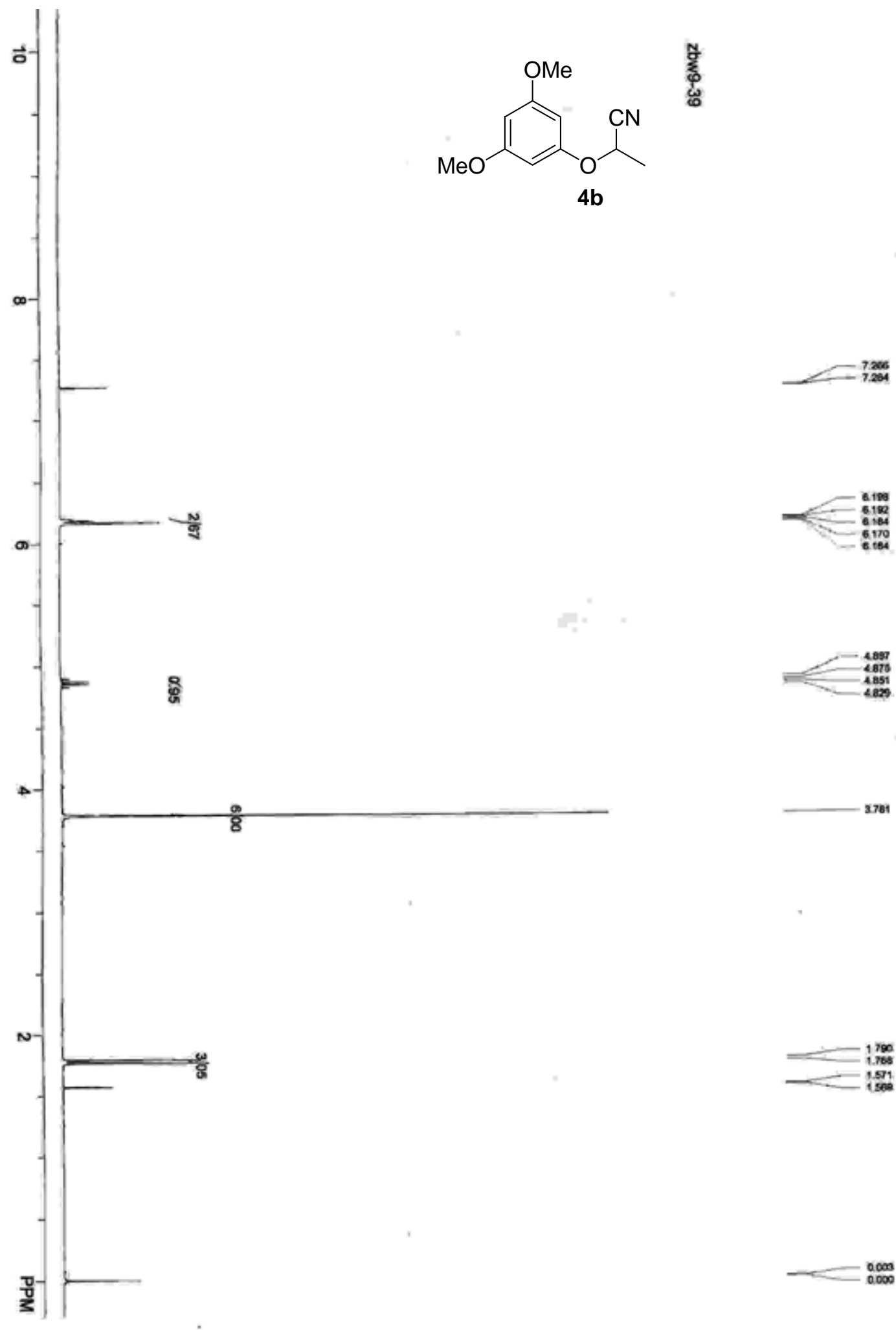

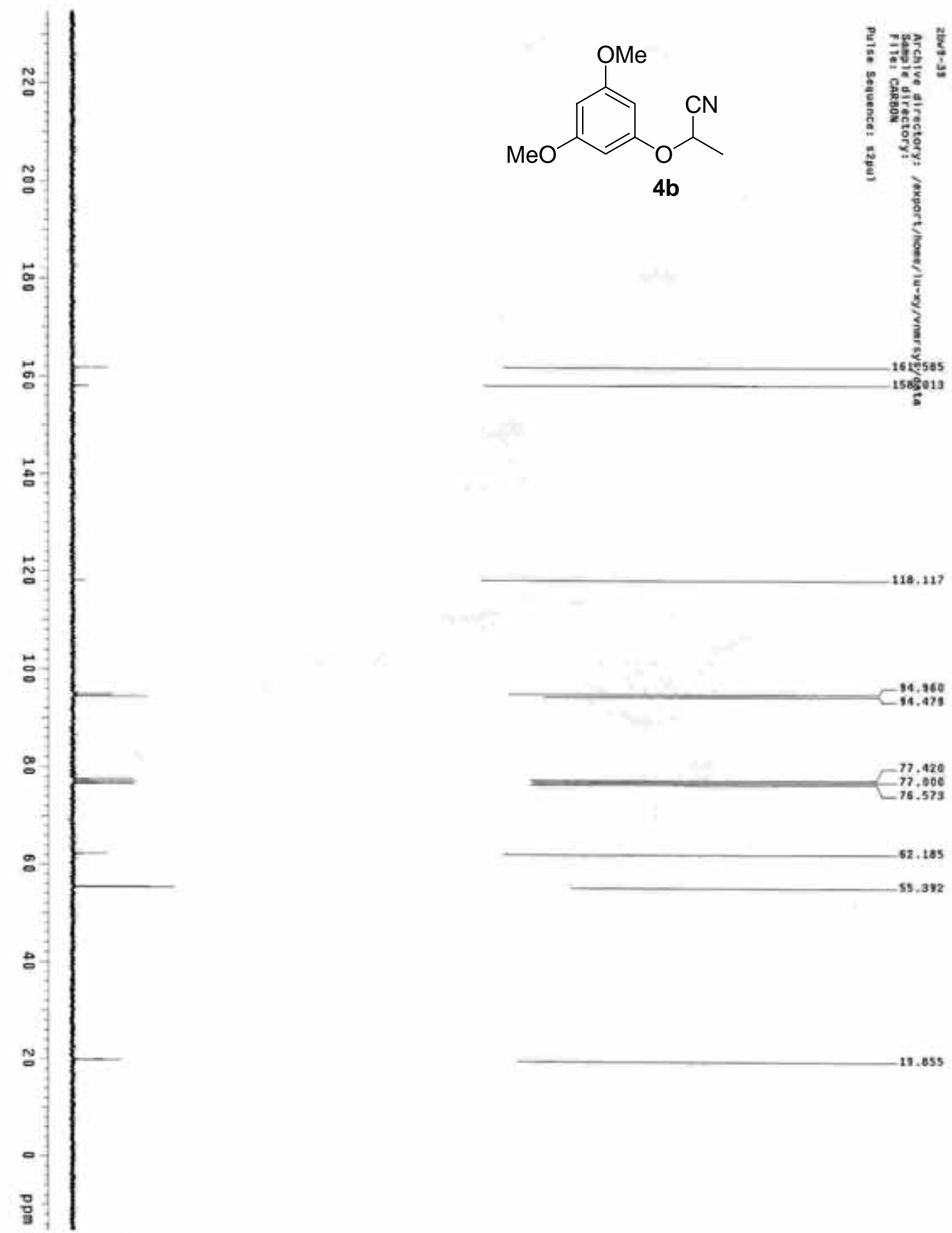

ร

94,36

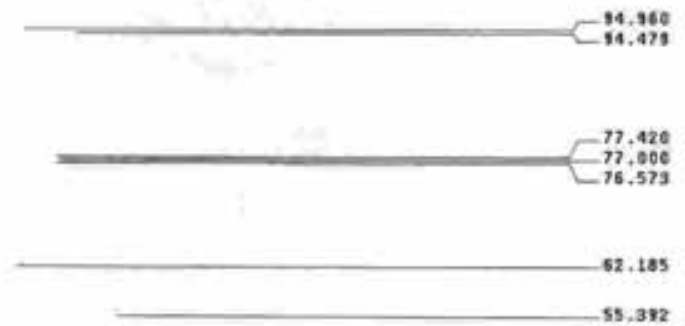

11. oss 


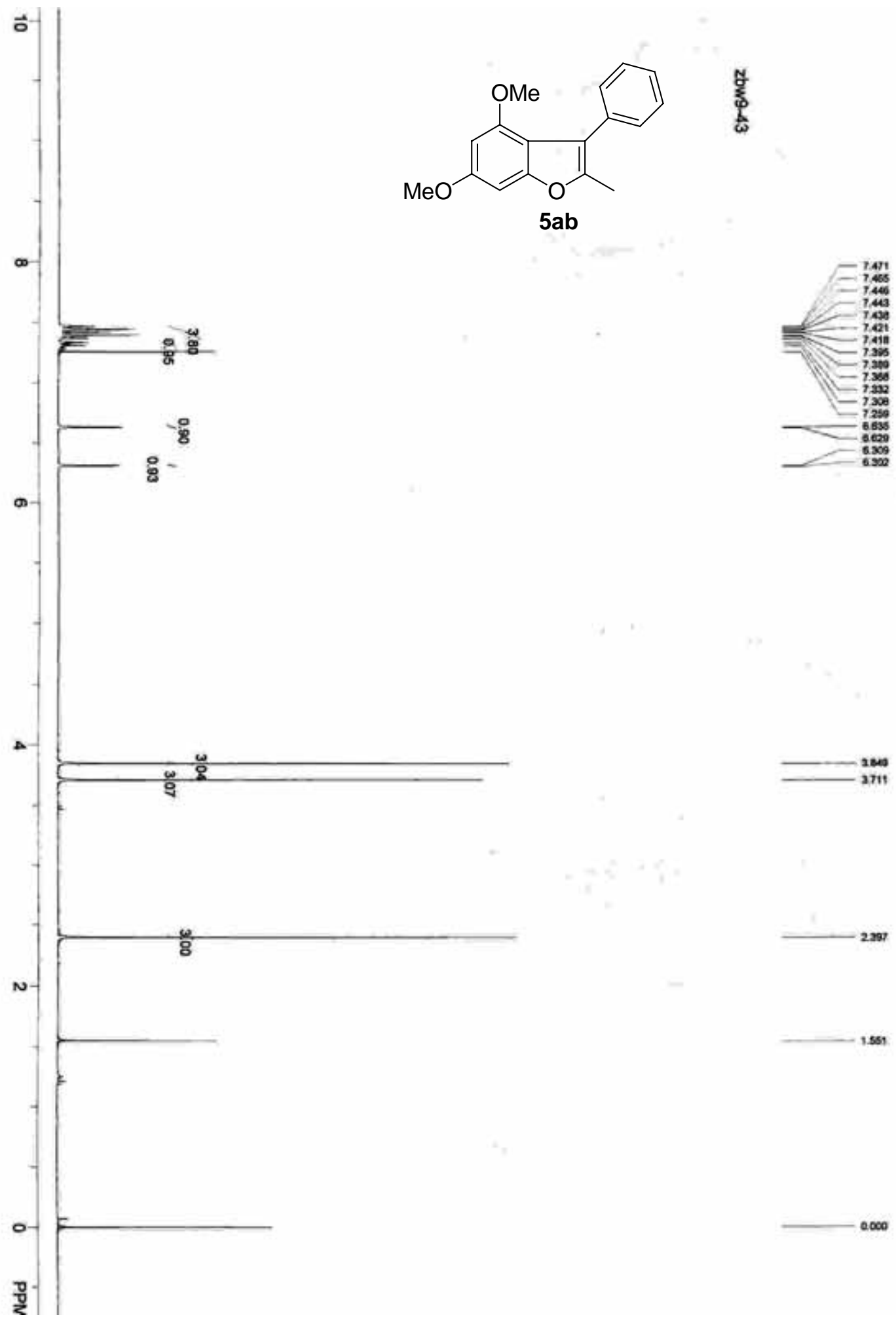



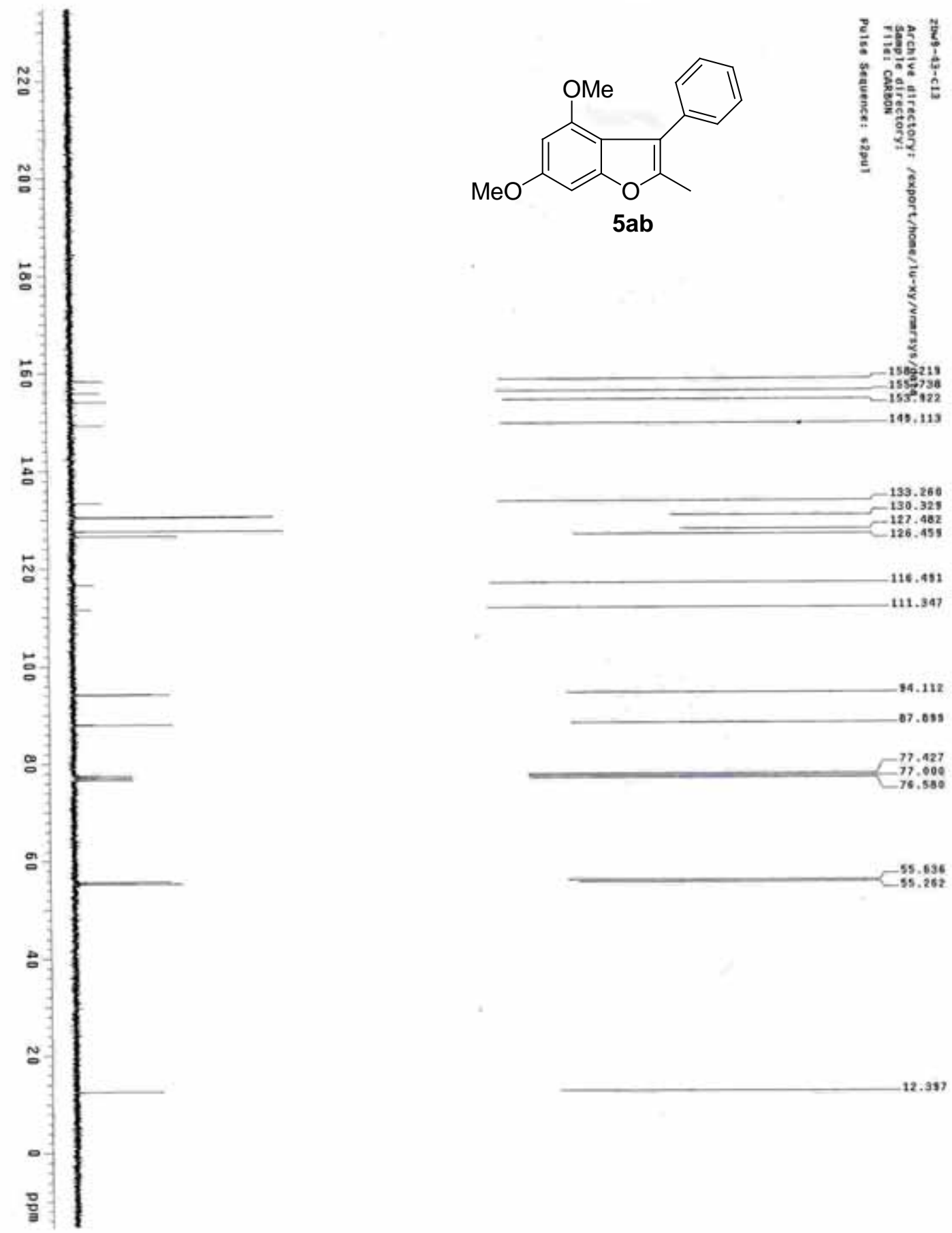

-55.636
-55.262

12.997 


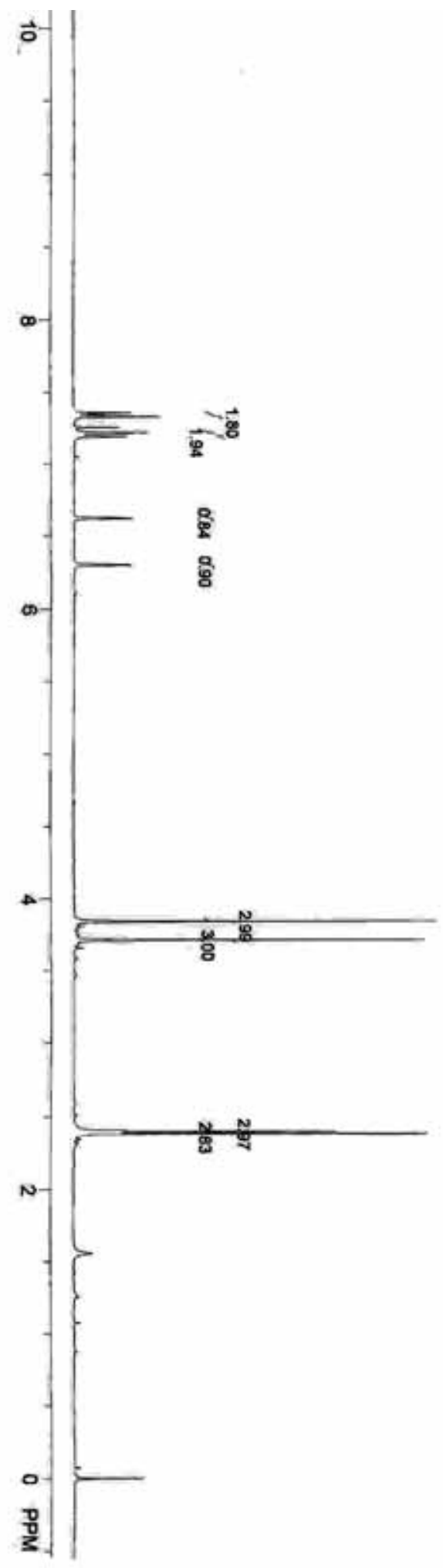



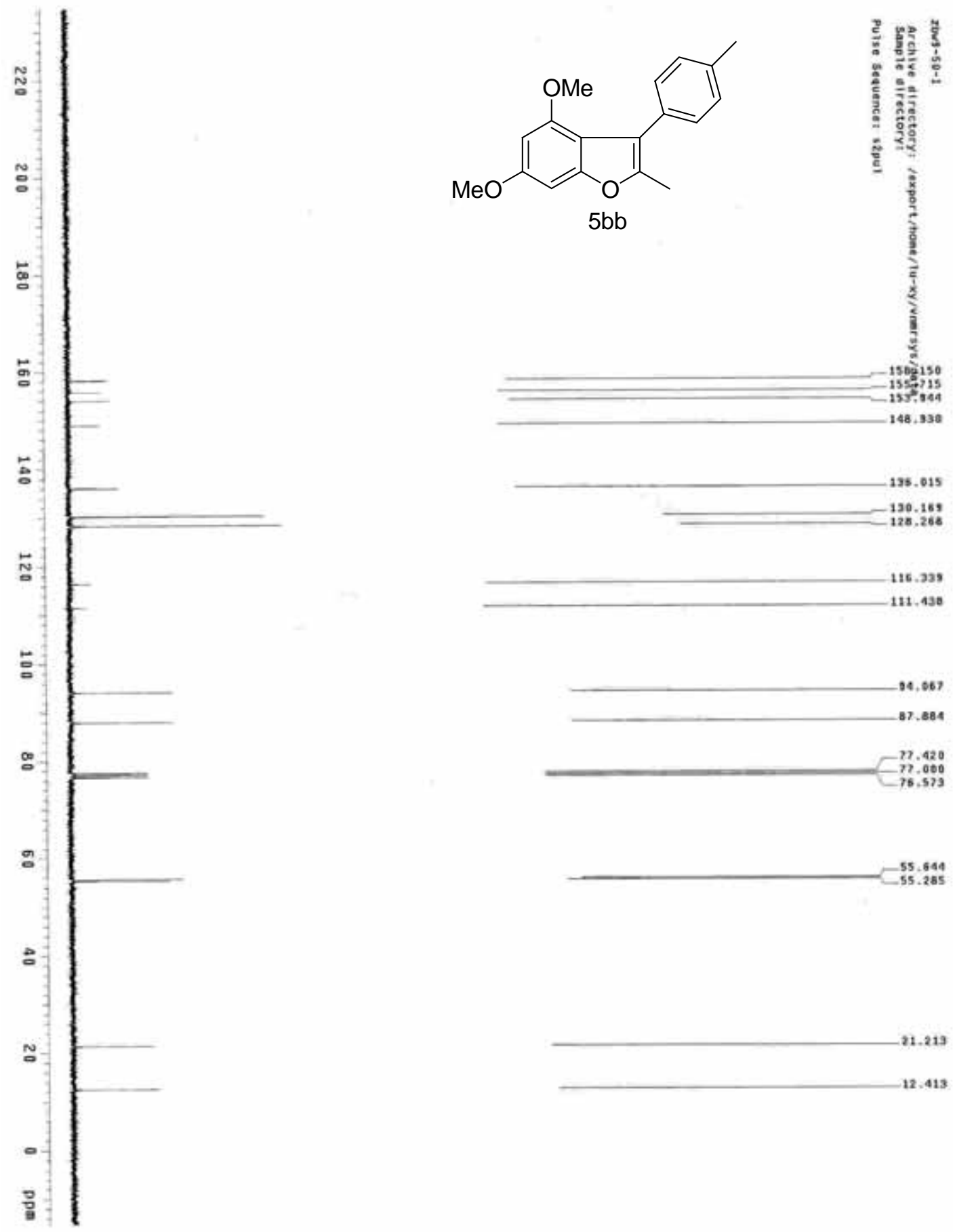

21.219

12. 413 


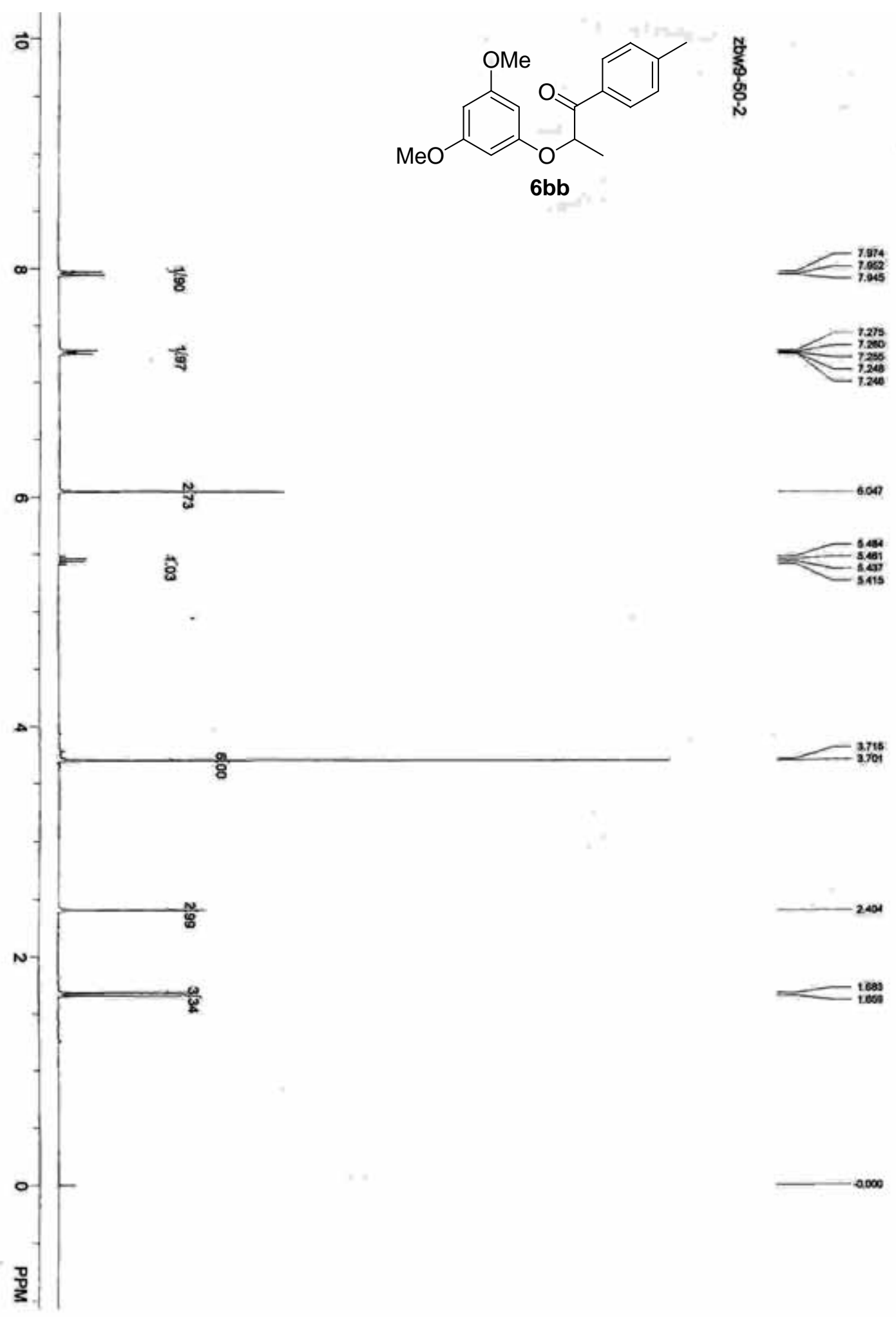




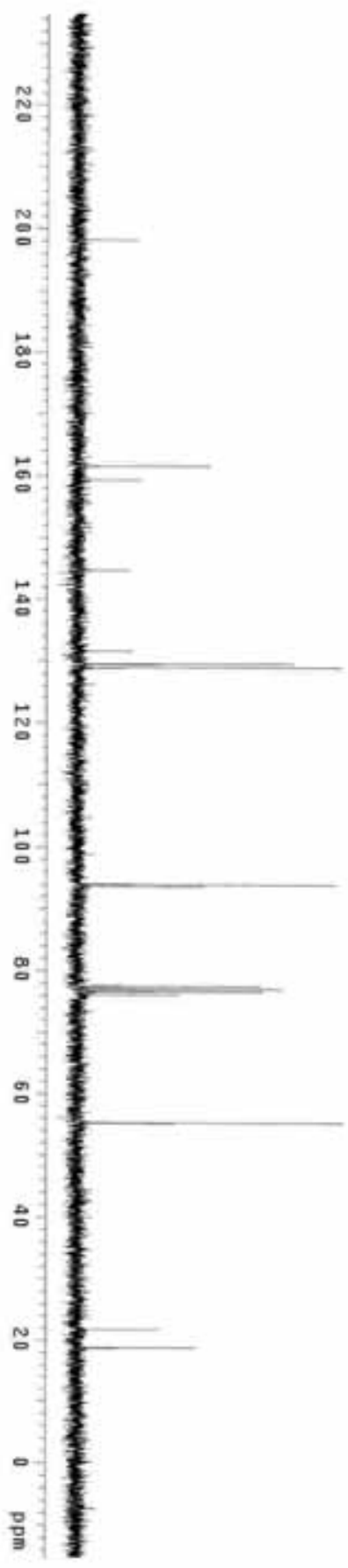<smiles>COc1cc(OC)cc(OC(C)C(=O)c2ccc(C)cc2)c1</smiles>
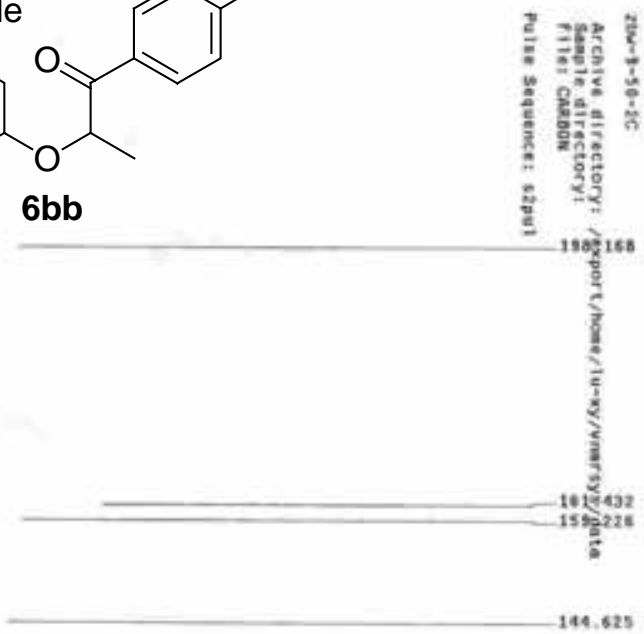

-131.520
12,494
$-12,496$

$-128.656$

-3.893
-3.502

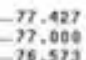

76.573
-76.651

21.685
10.671 


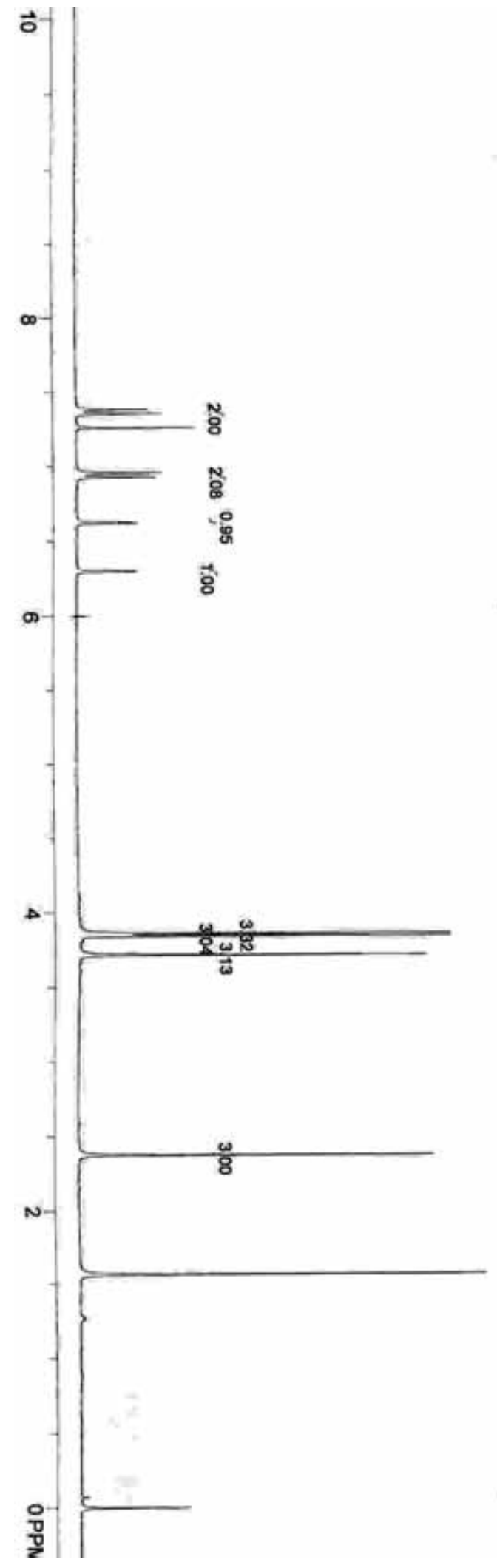<smiles>COc1ccc(-c2c(C)oc3cc(OC)cc(OC)c23)cc1</smiles>
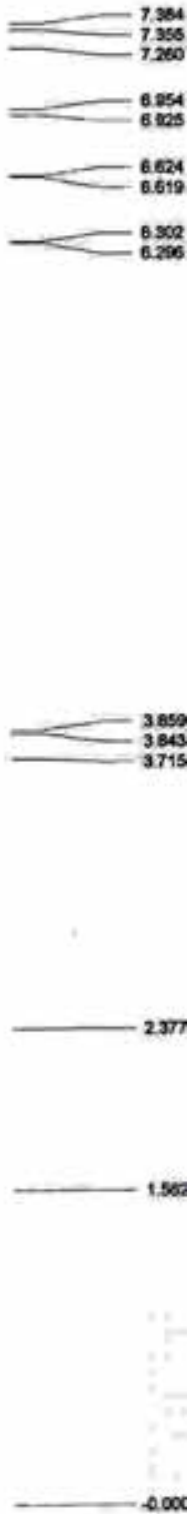

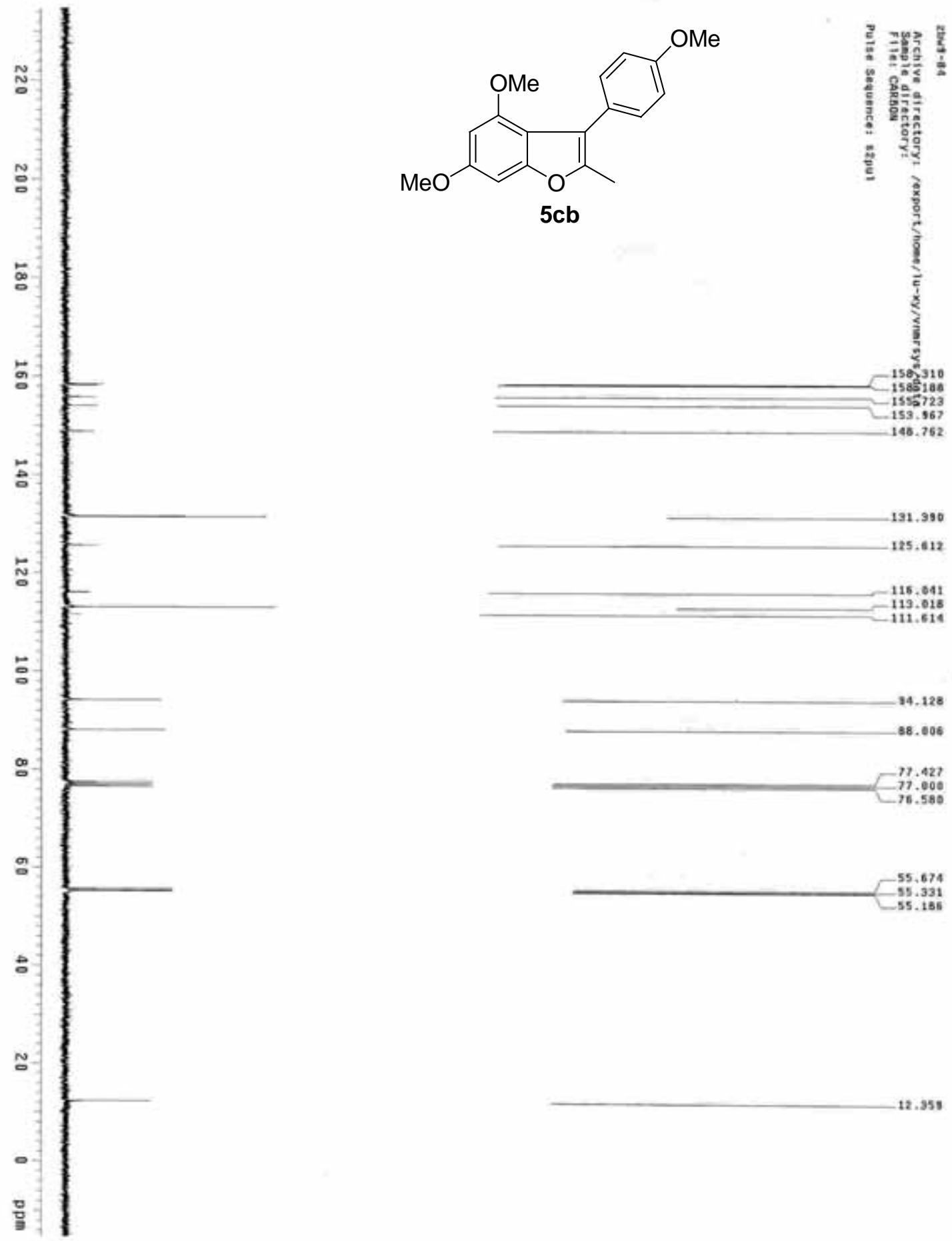

131.990

125.412

115.641

119.018
-111.518

$-94.128$

$-88.006$

$-77.427$

$-76.580$

$-55.674$

55.131
-55.156

$-12.358$ 


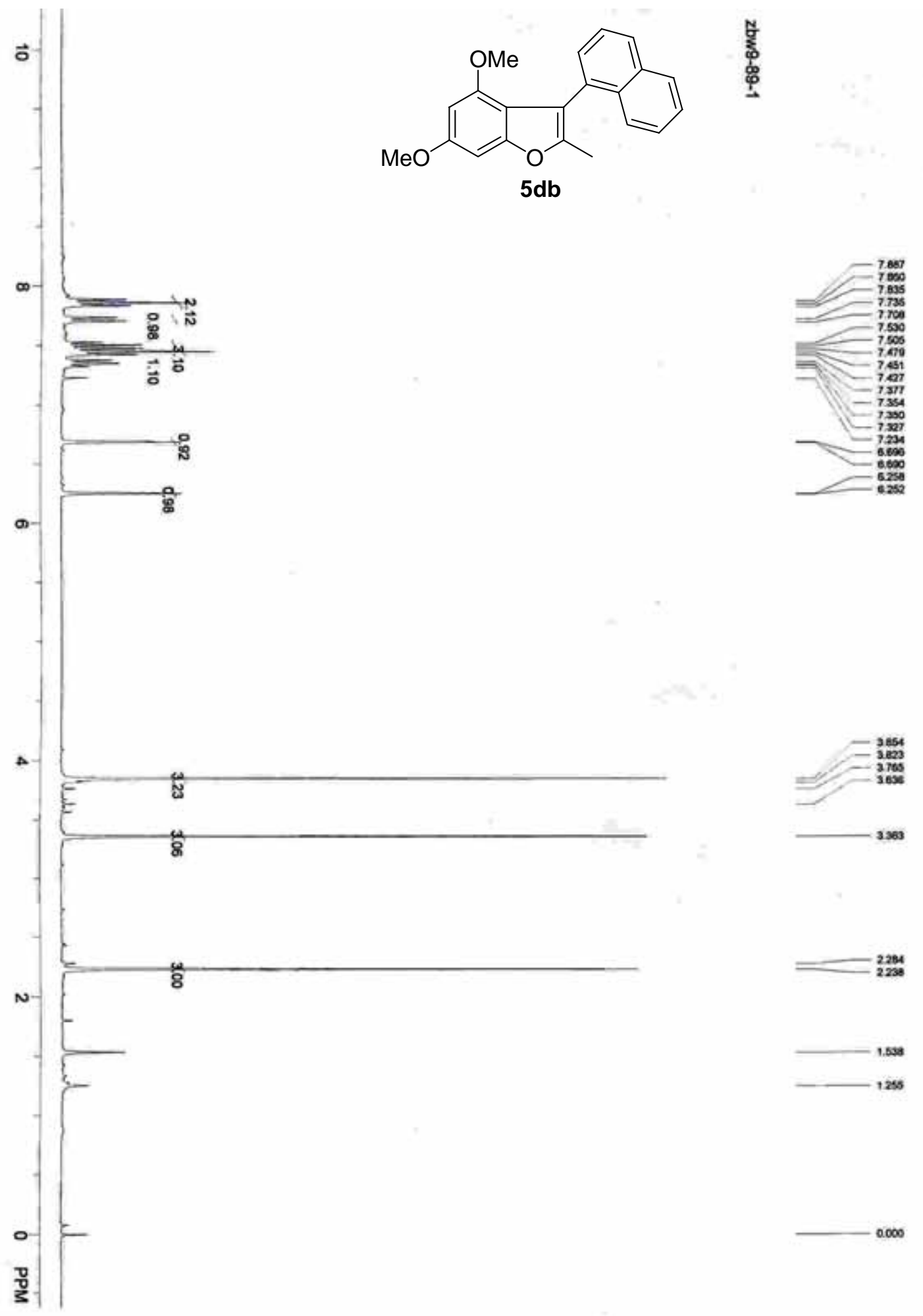



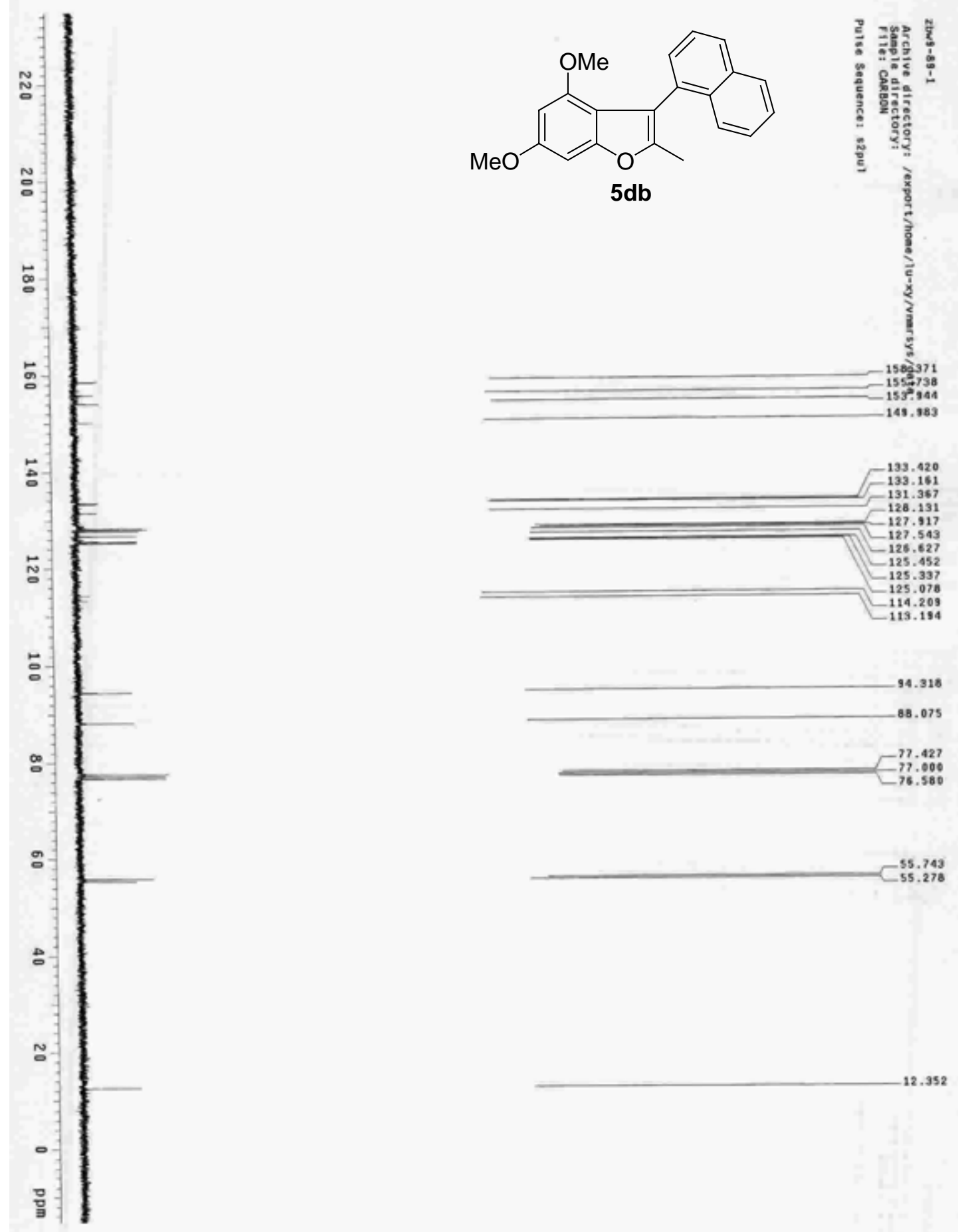

-55.743
-55.278

12.352 


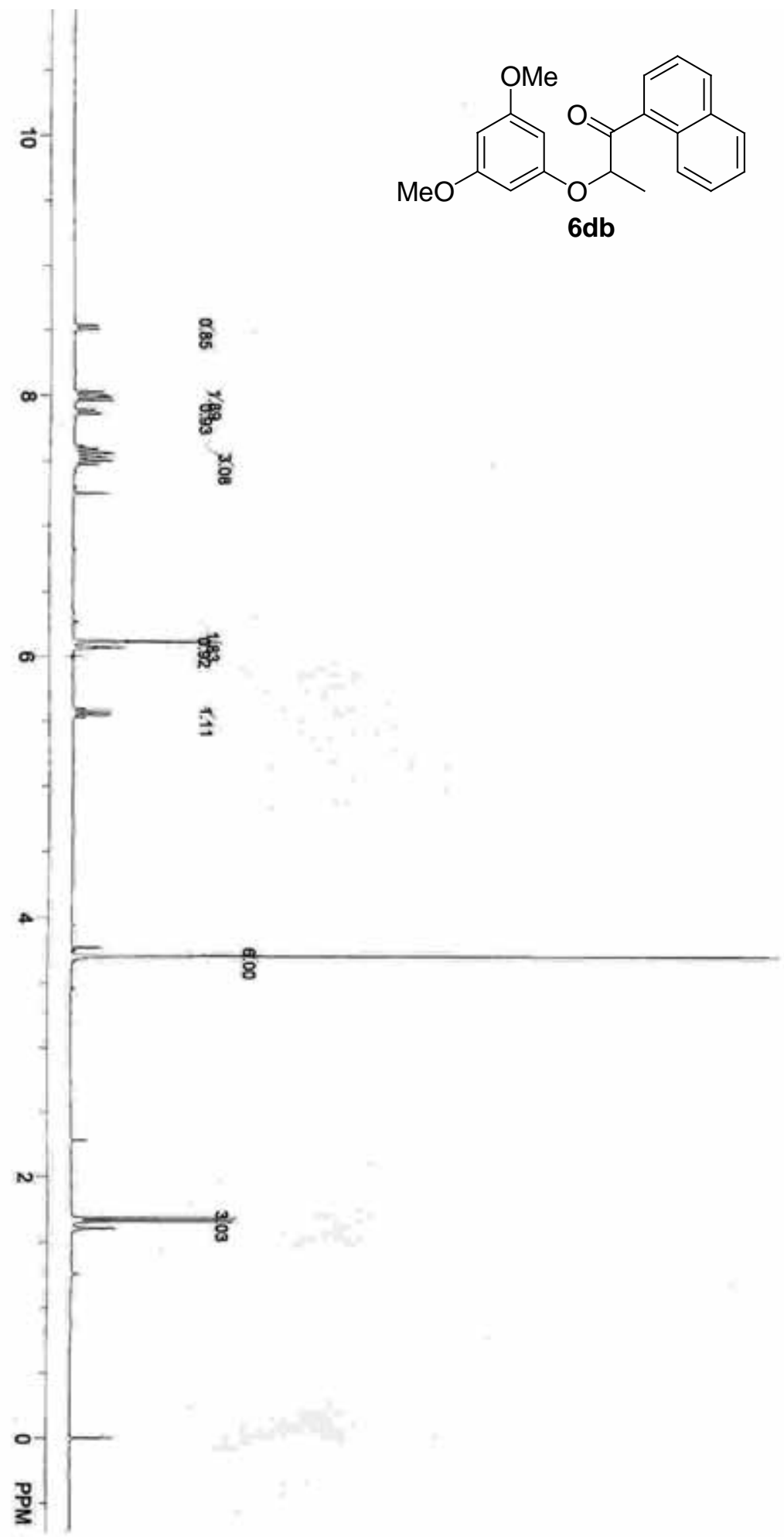

ญํํ
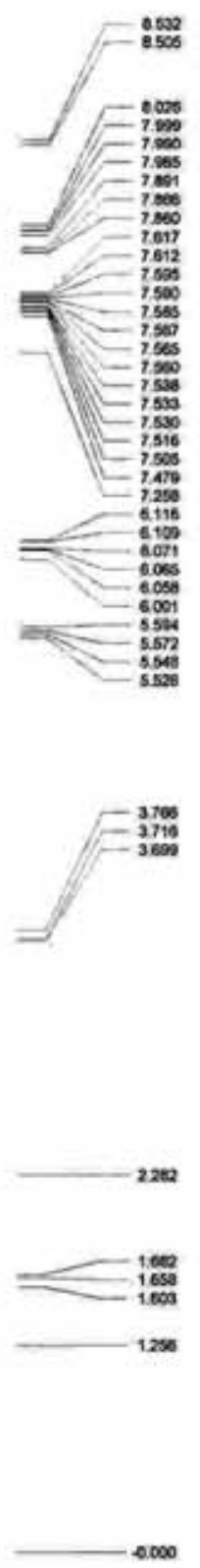

ㅁํำ 


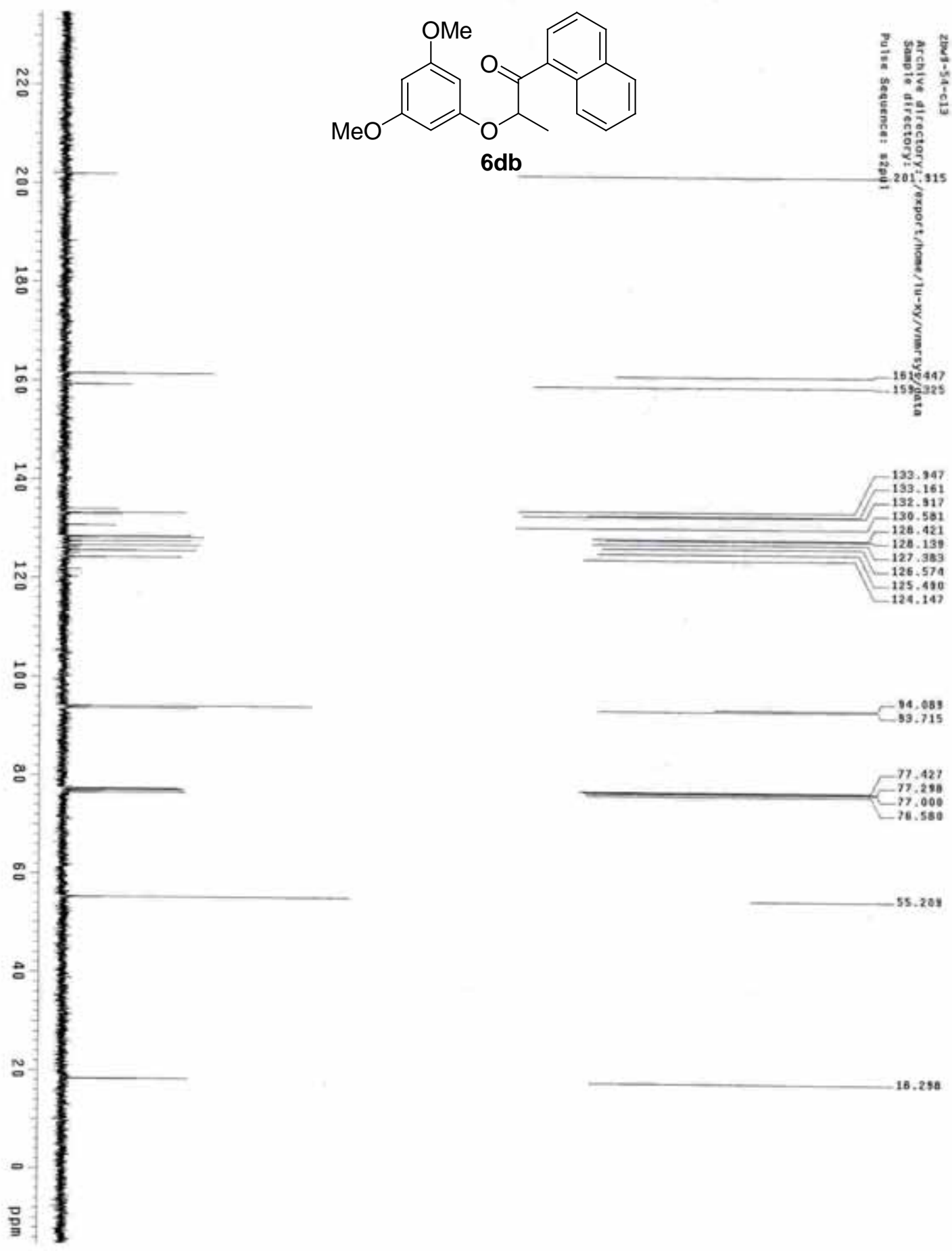




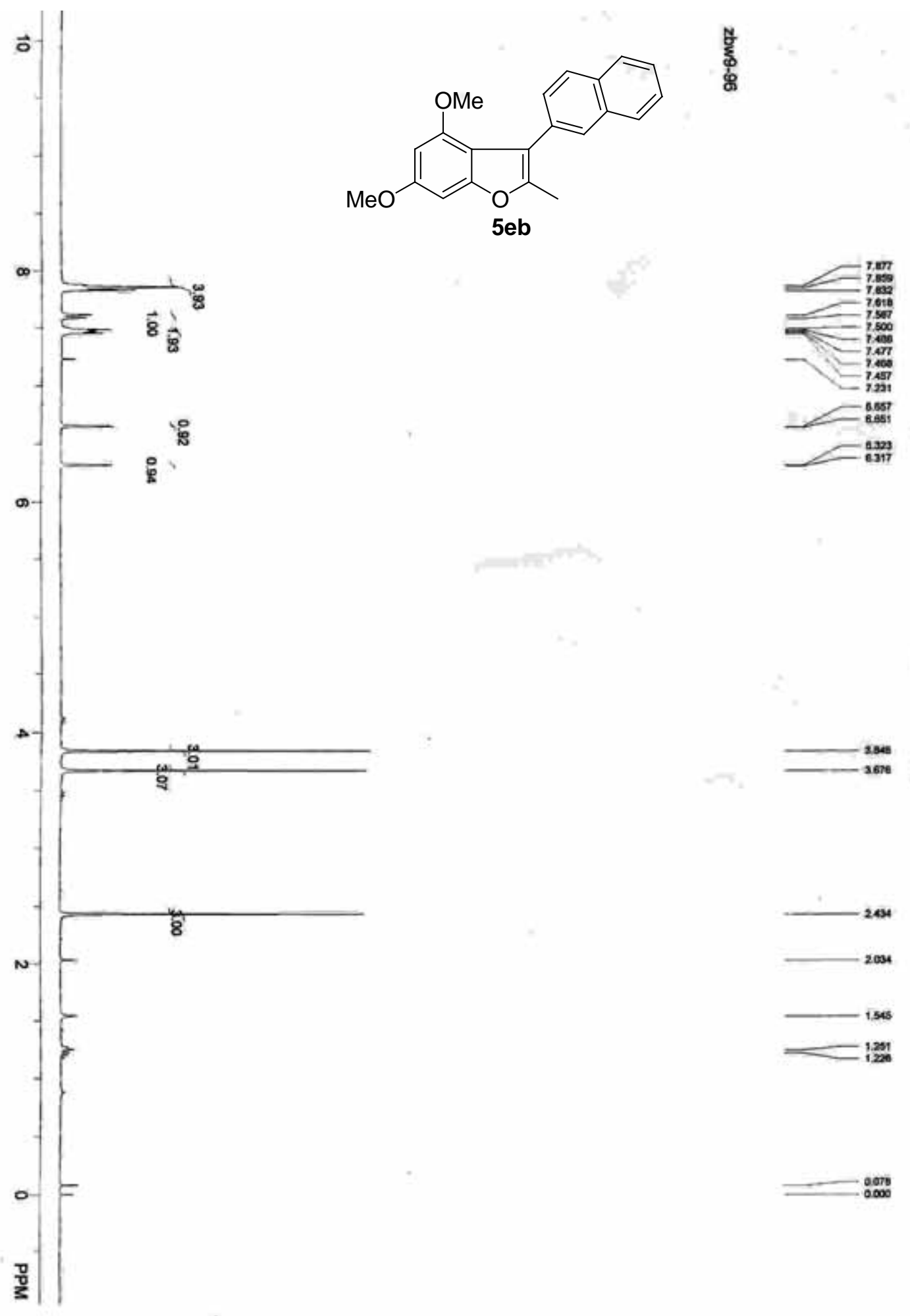




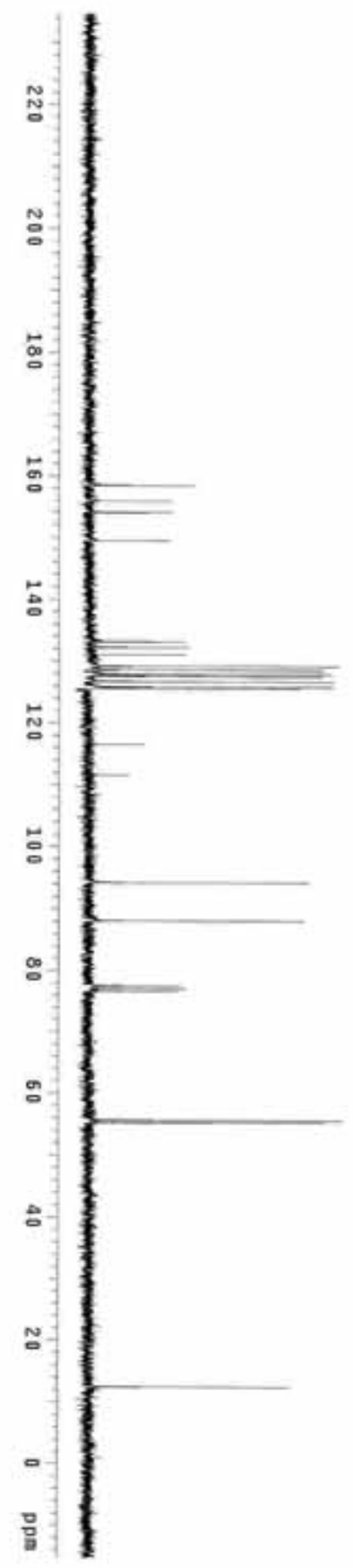<smiles>COc1cc(OC)c2c(-c3ccc4ccccc4c3)c(C)oc2c1</smiles>

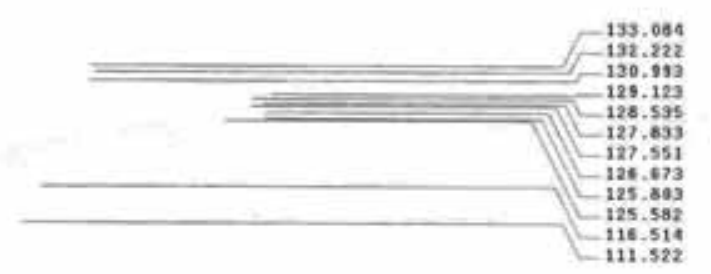

.514

$-94.169$

$-58.014$

$-77.420$

-

55.629
55.232

$-12.420$ 


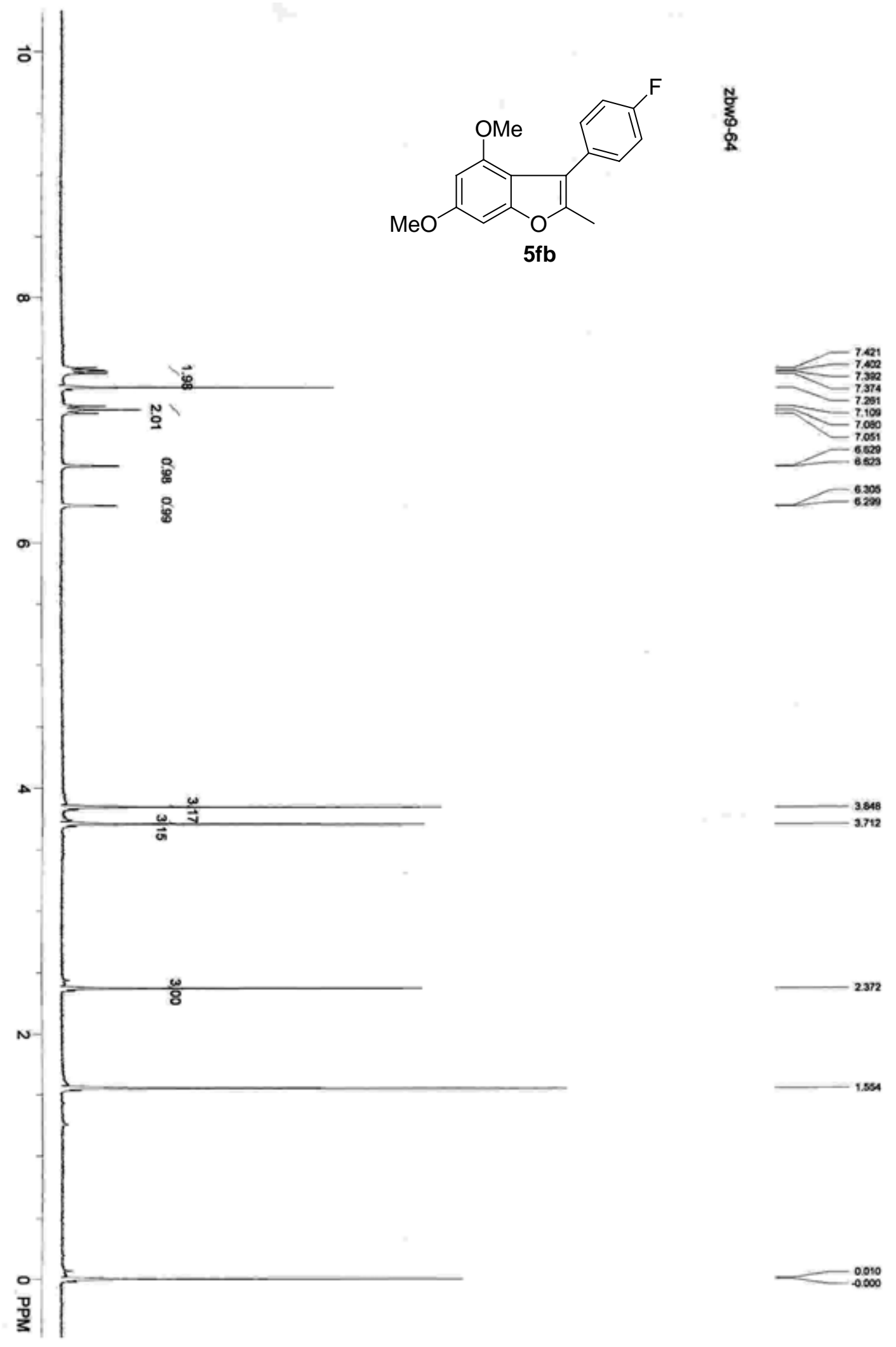



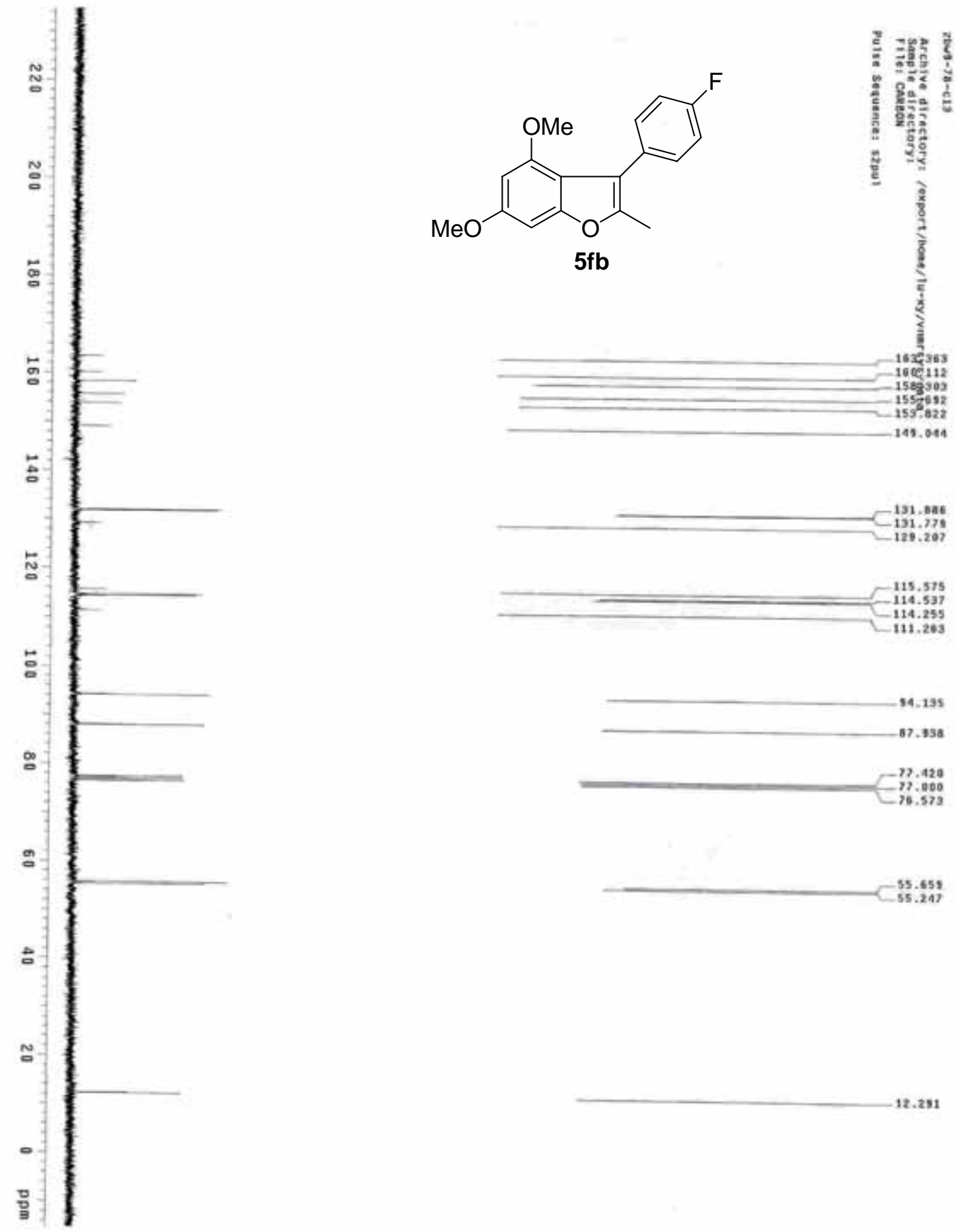

131.896
131.778

-131.778
-129.207

118.575
-114.537

114.255

111.203
-114.259

.4. 195

$-87.938$

77.420
-7.000

$-76.573$

-55.659
-55.247

$-12.281$ 


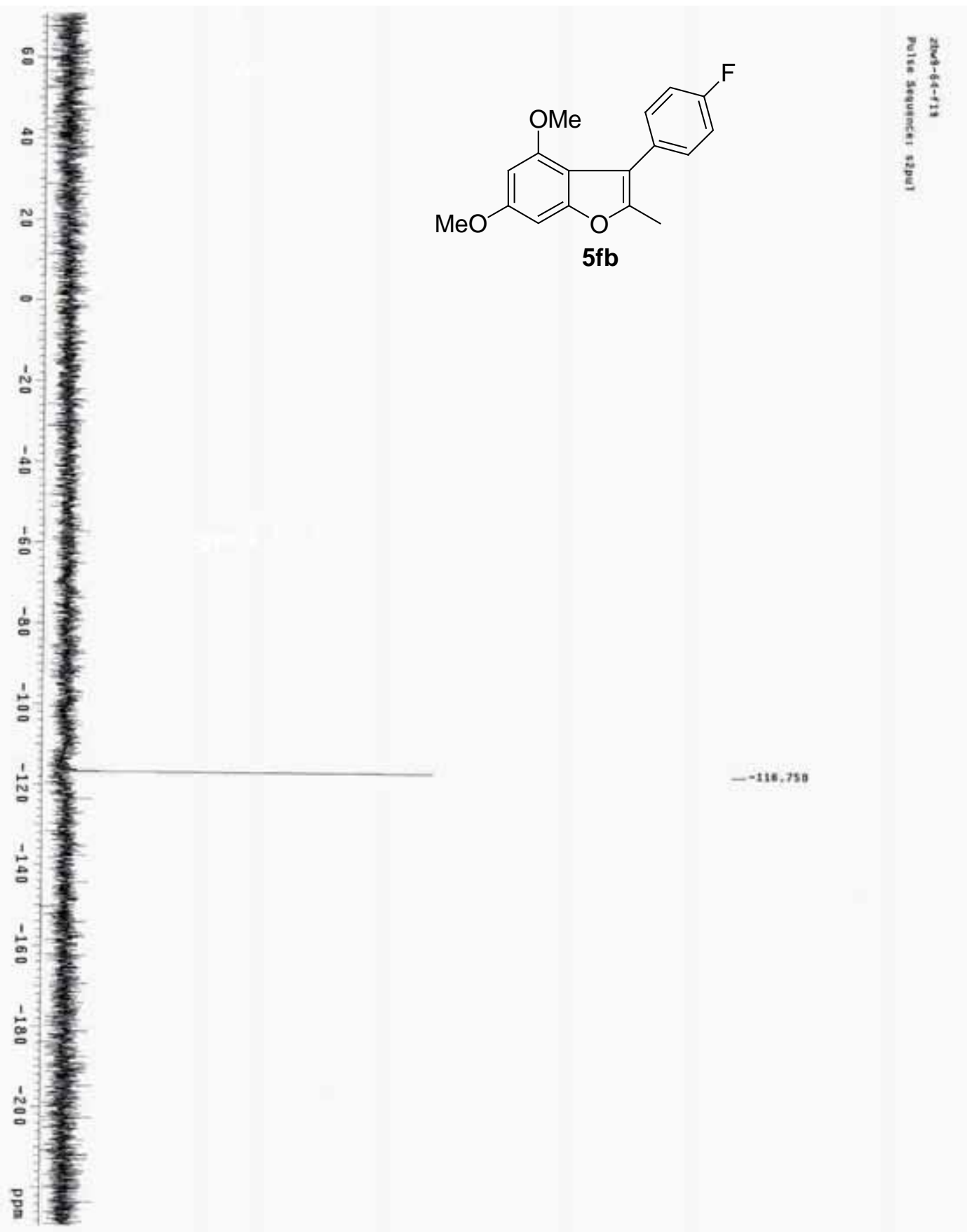



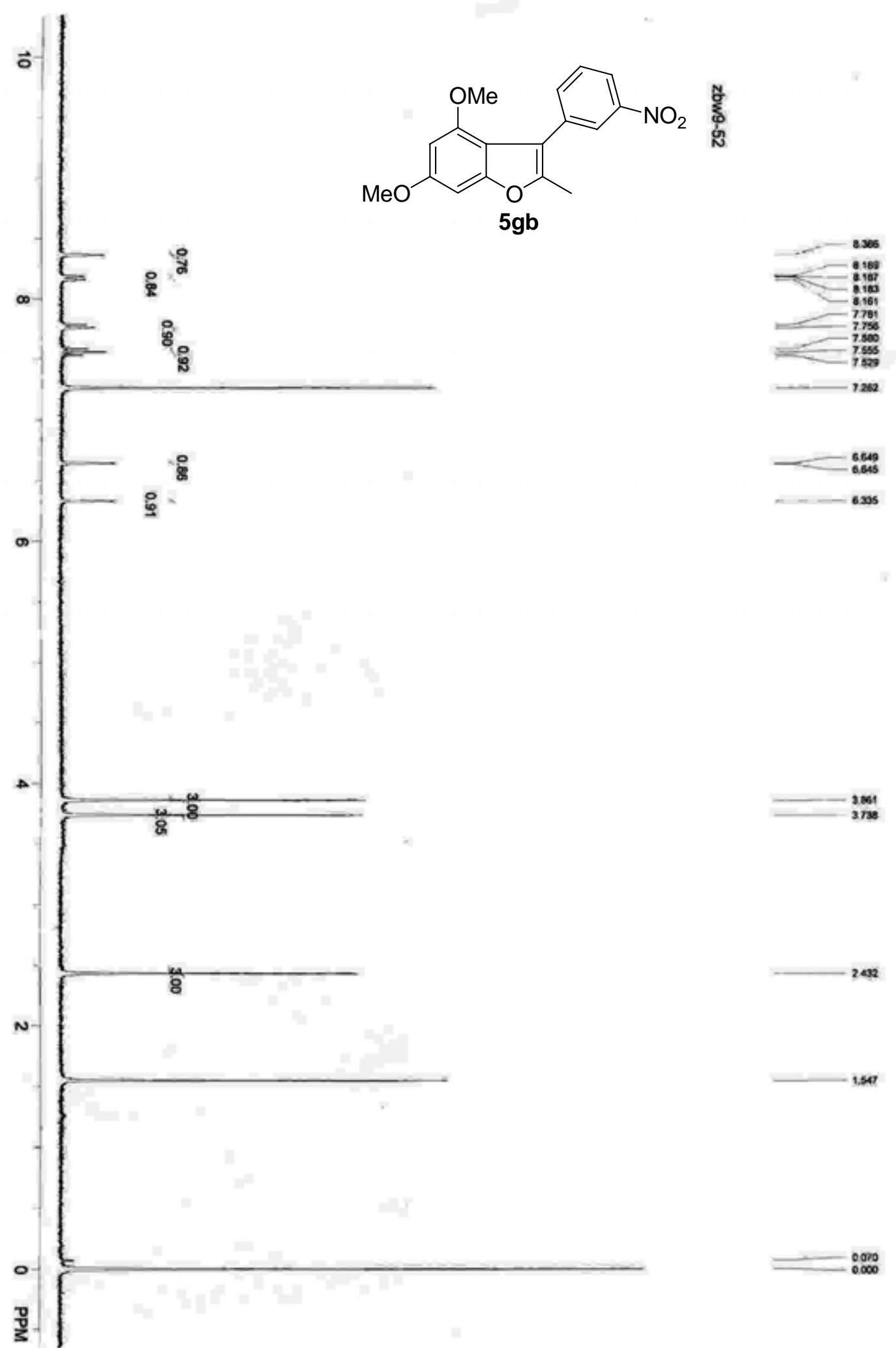

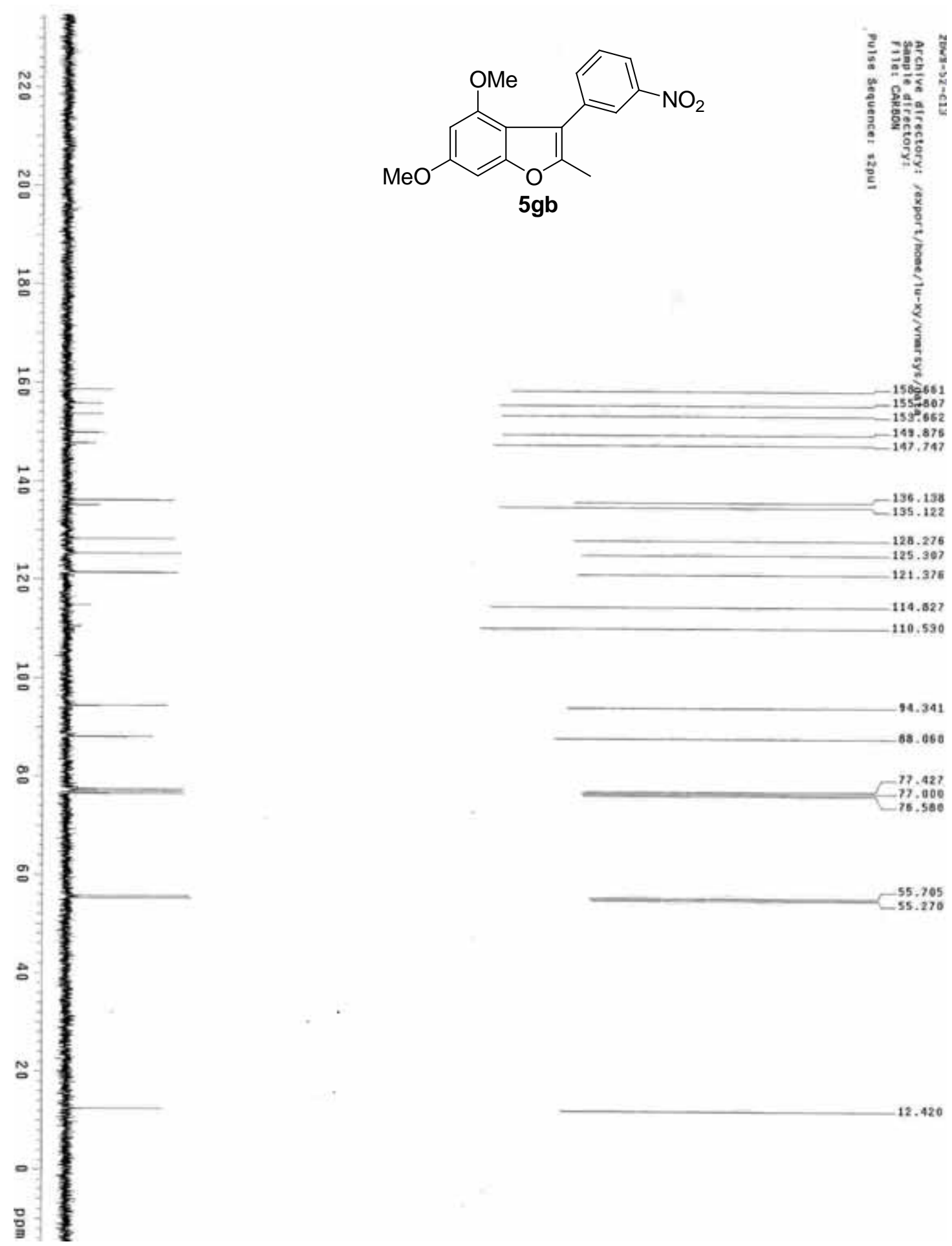

55.705
-55.270

$-12.420$ 


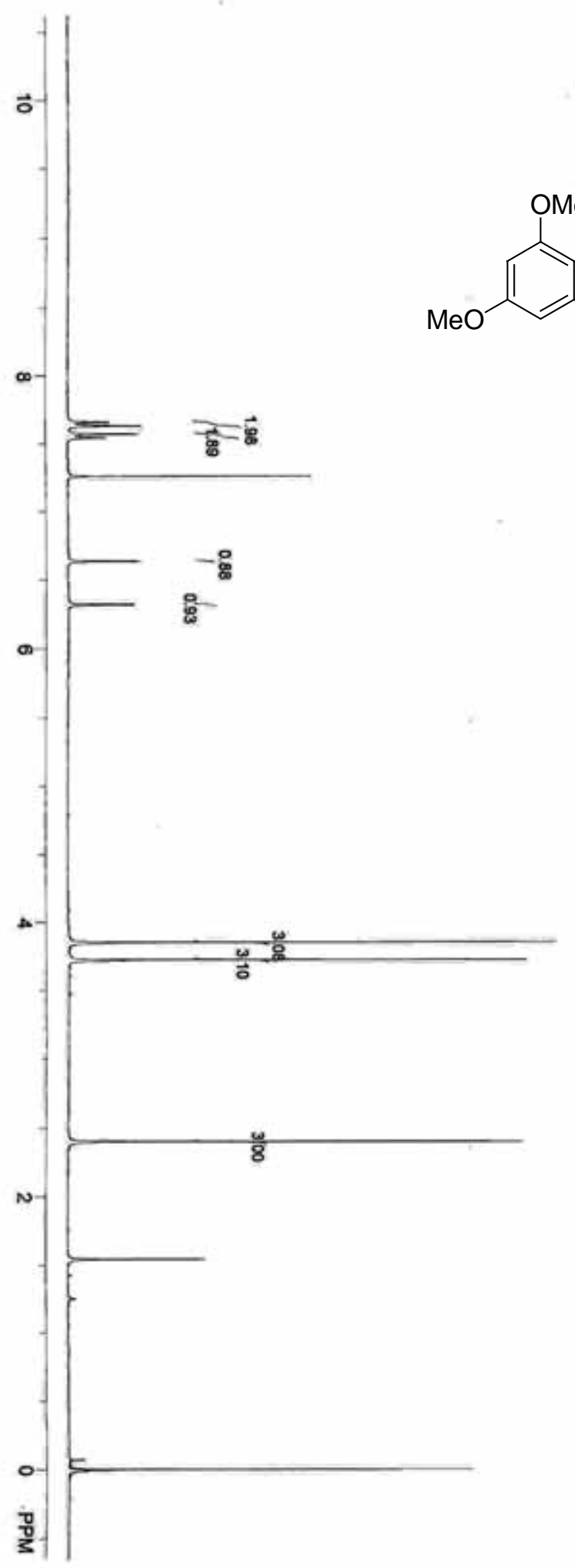

蒿

$5 \mathrm{hb}$
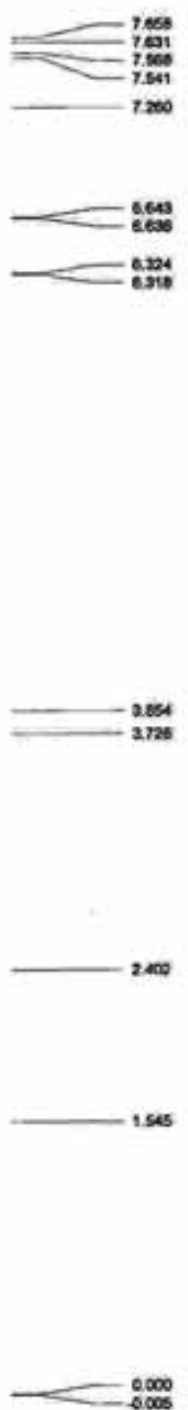

0.000
$-\quad 0005$ 


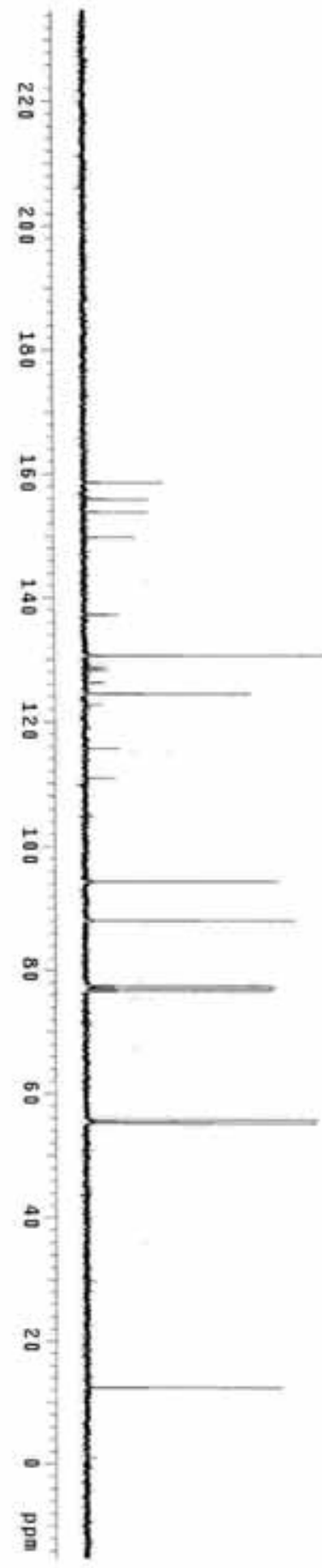<smiles></smiles>

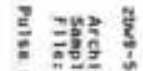

政

$5 \mathrm{hb}$

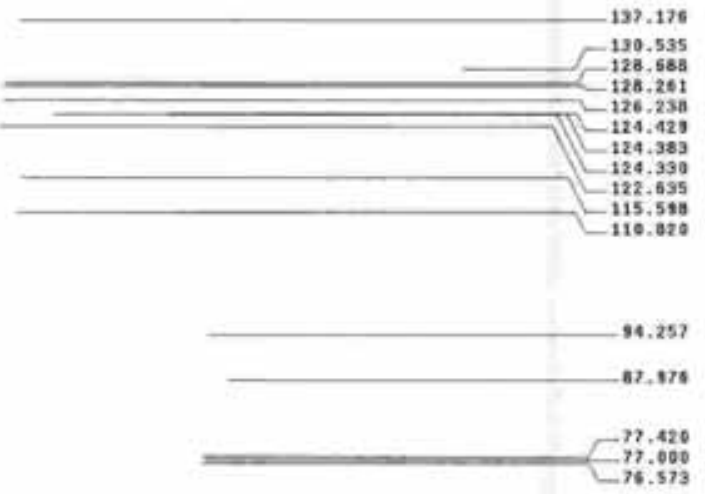

-55.597
-55.290

12,428 

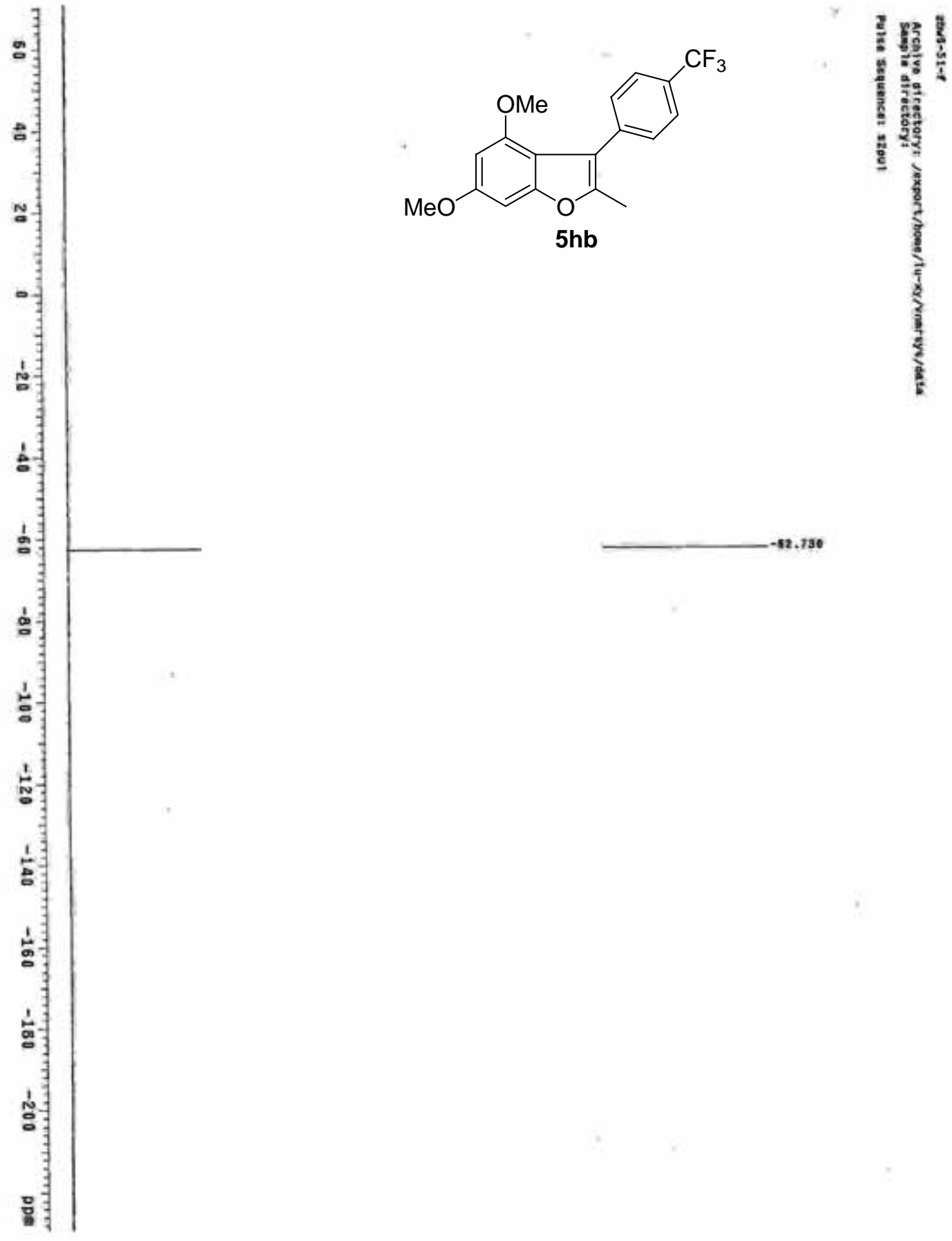


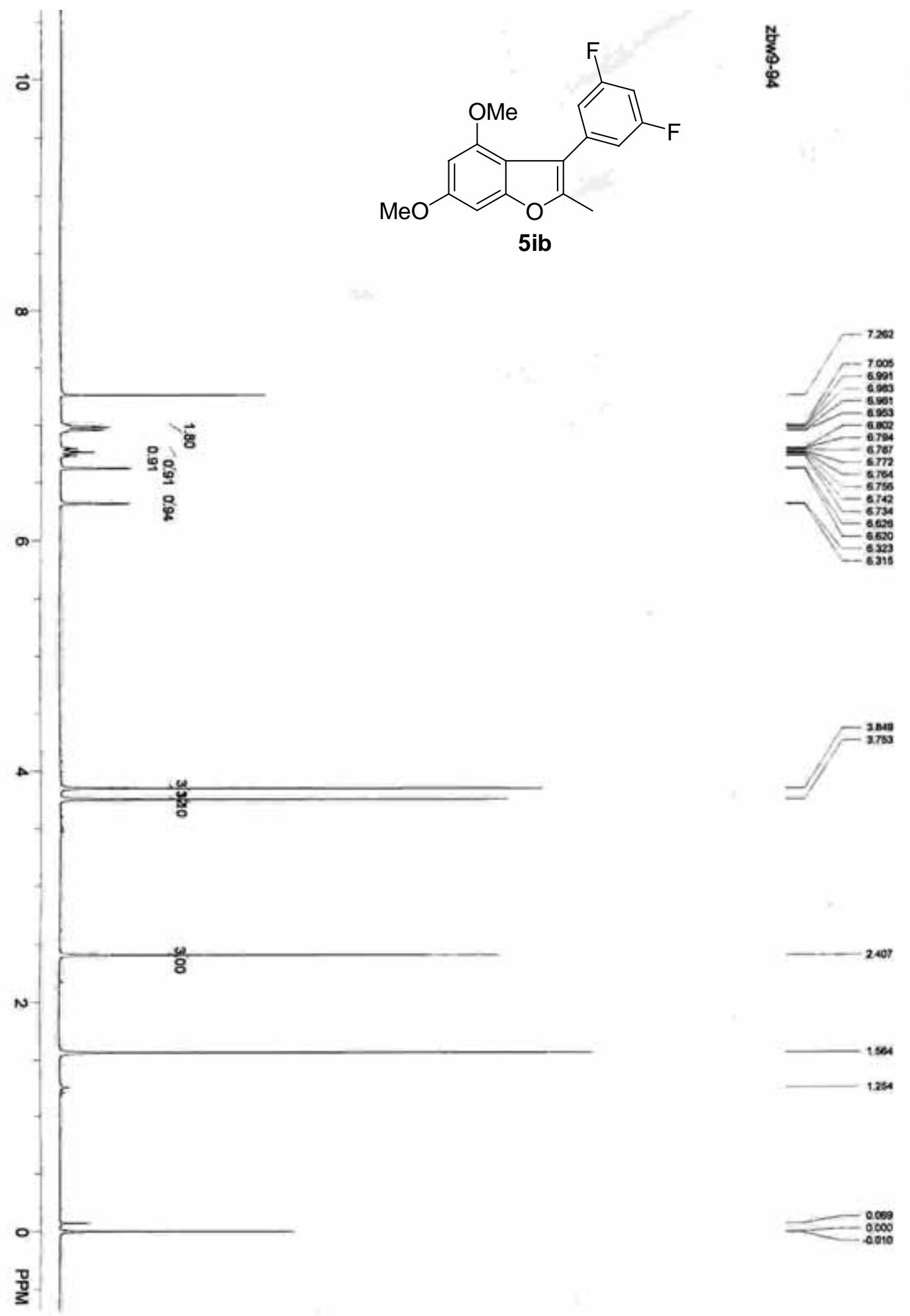



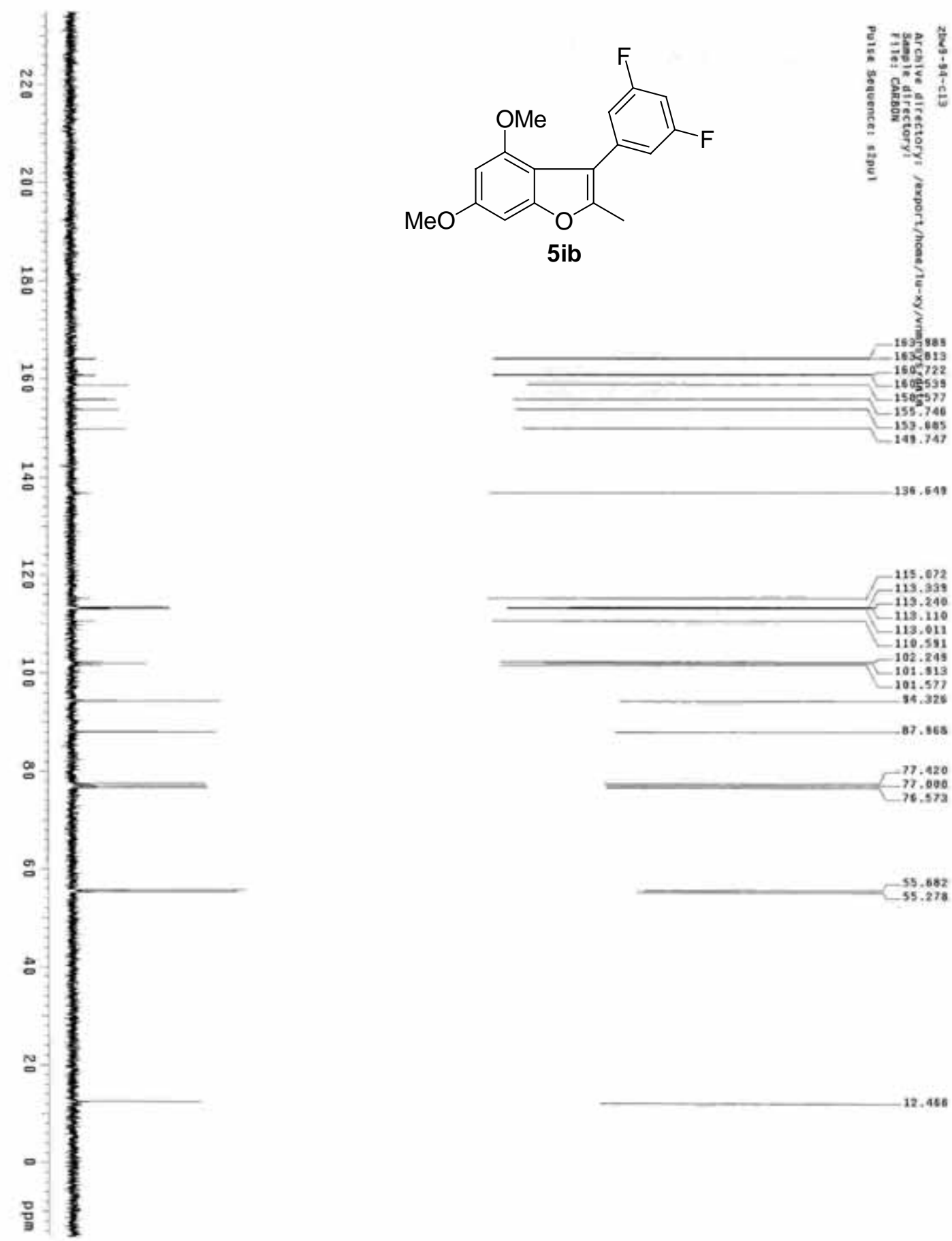

-55.682
-55.278

7.000
6.573

12,456 

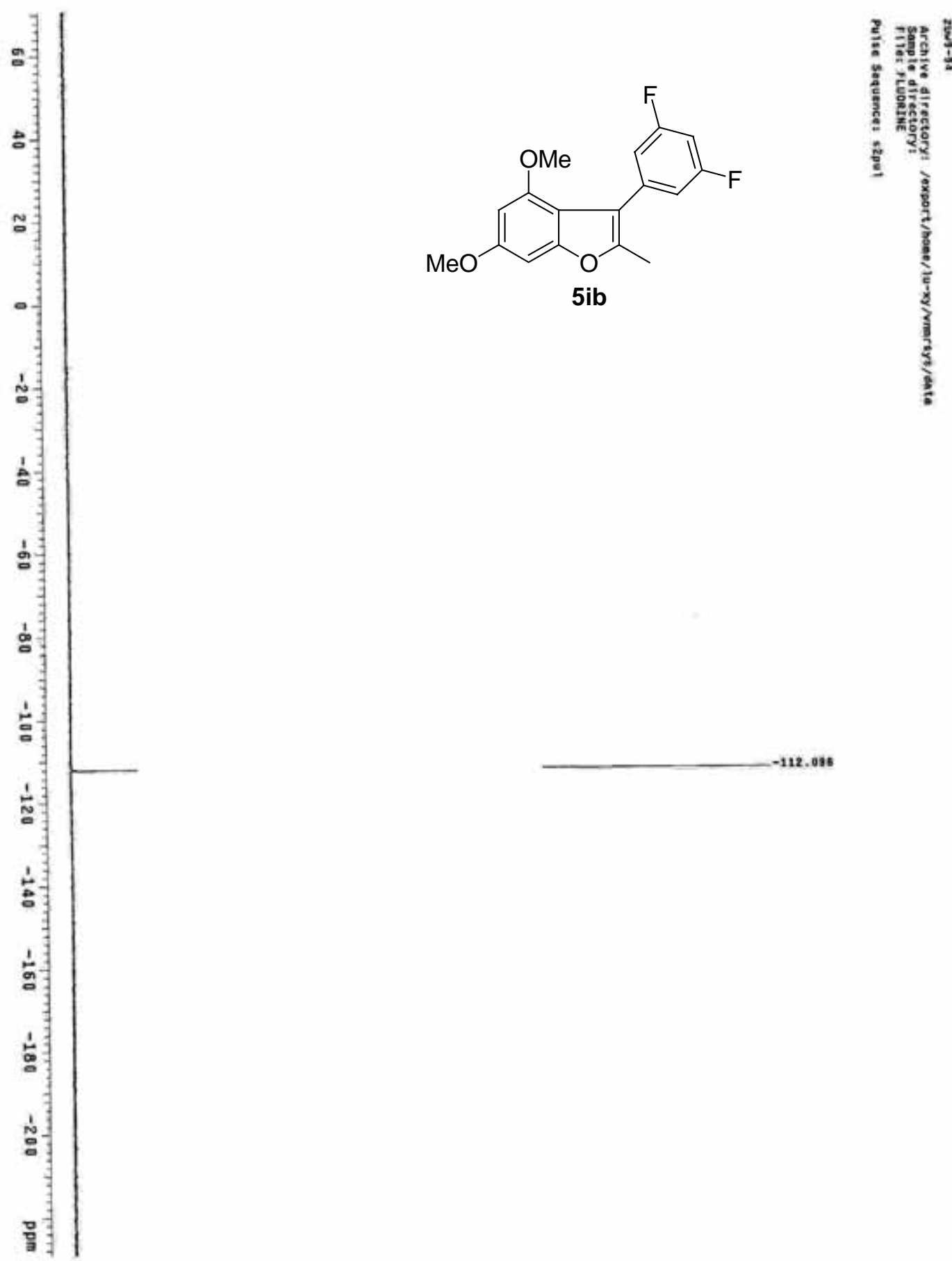

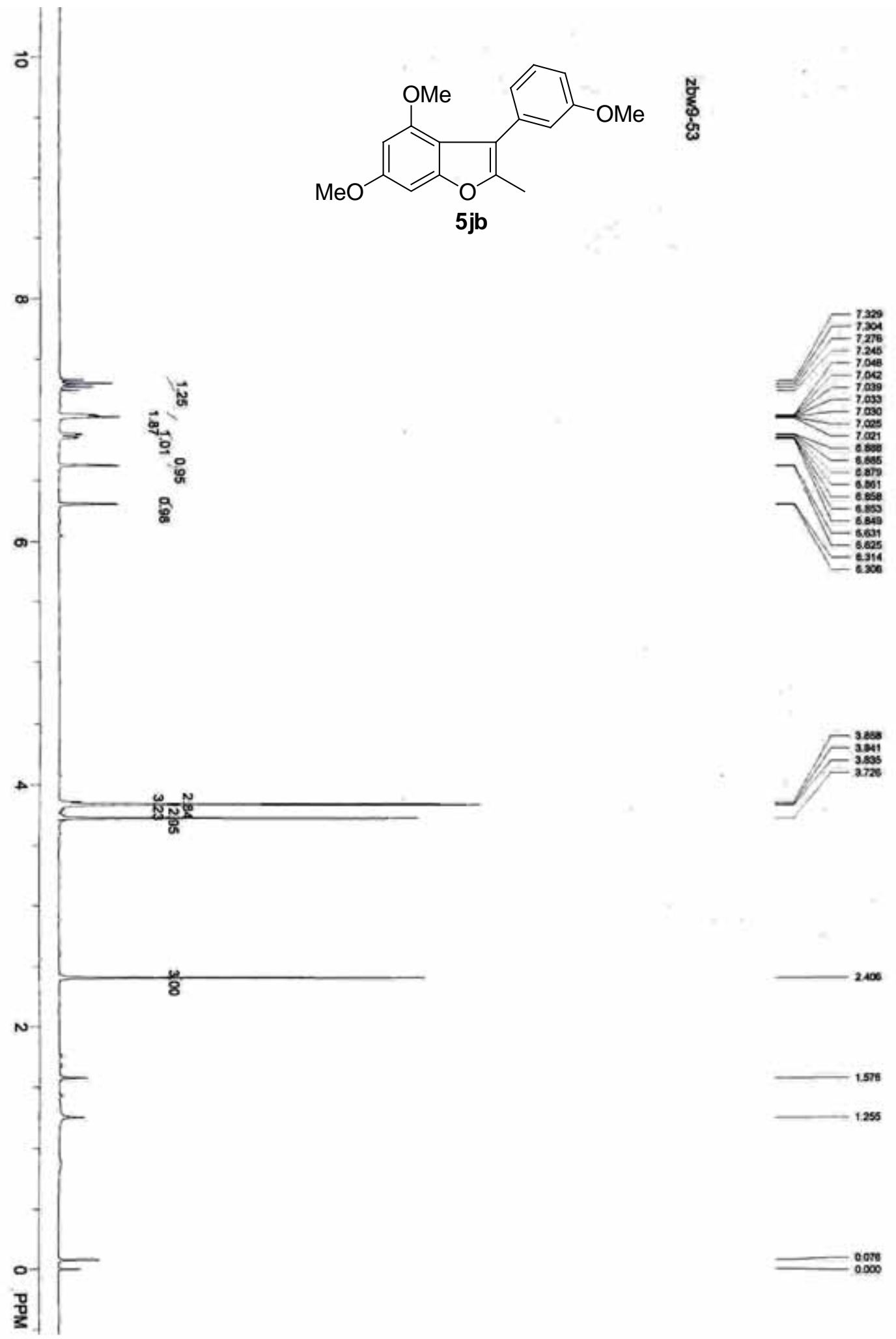

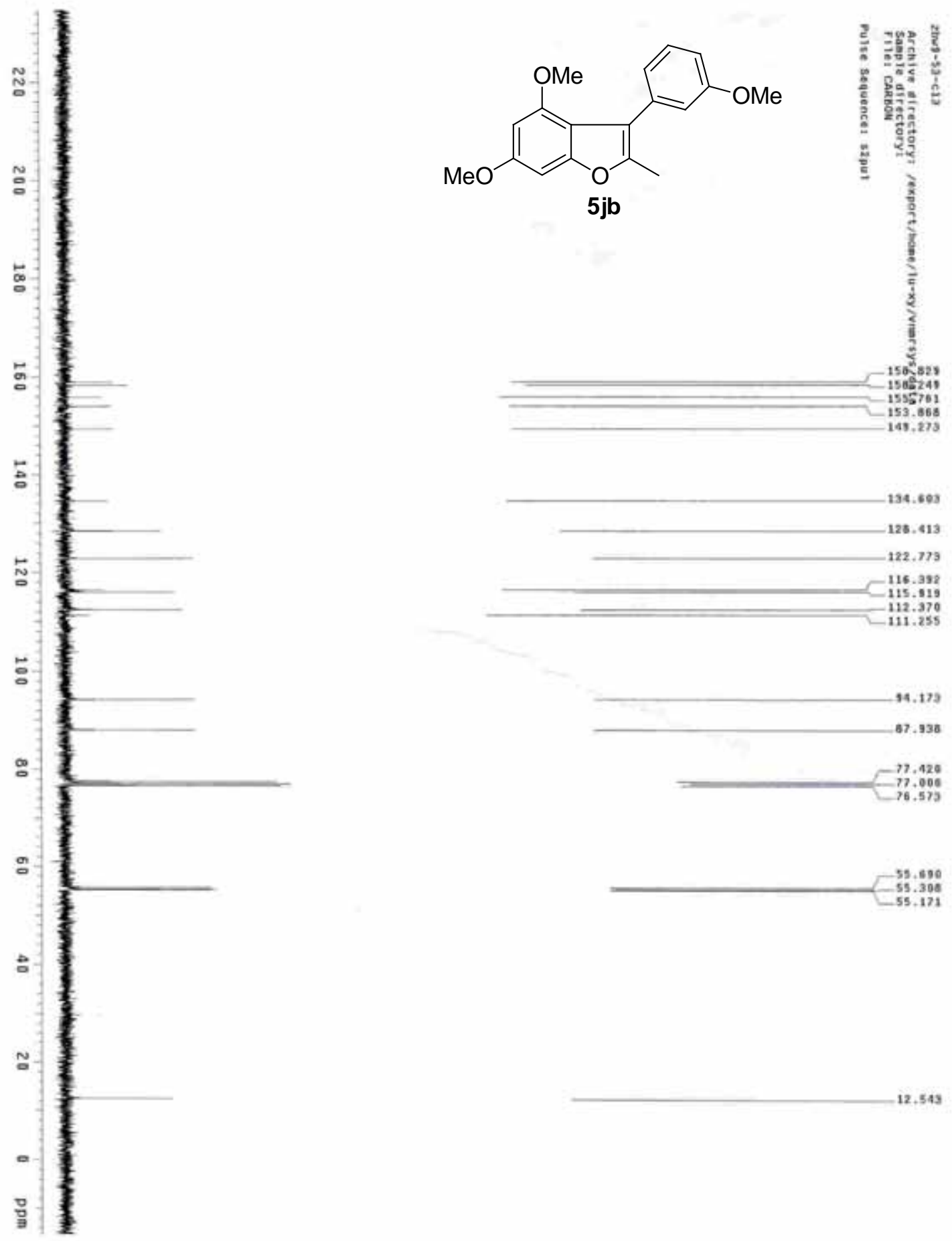

12.543 


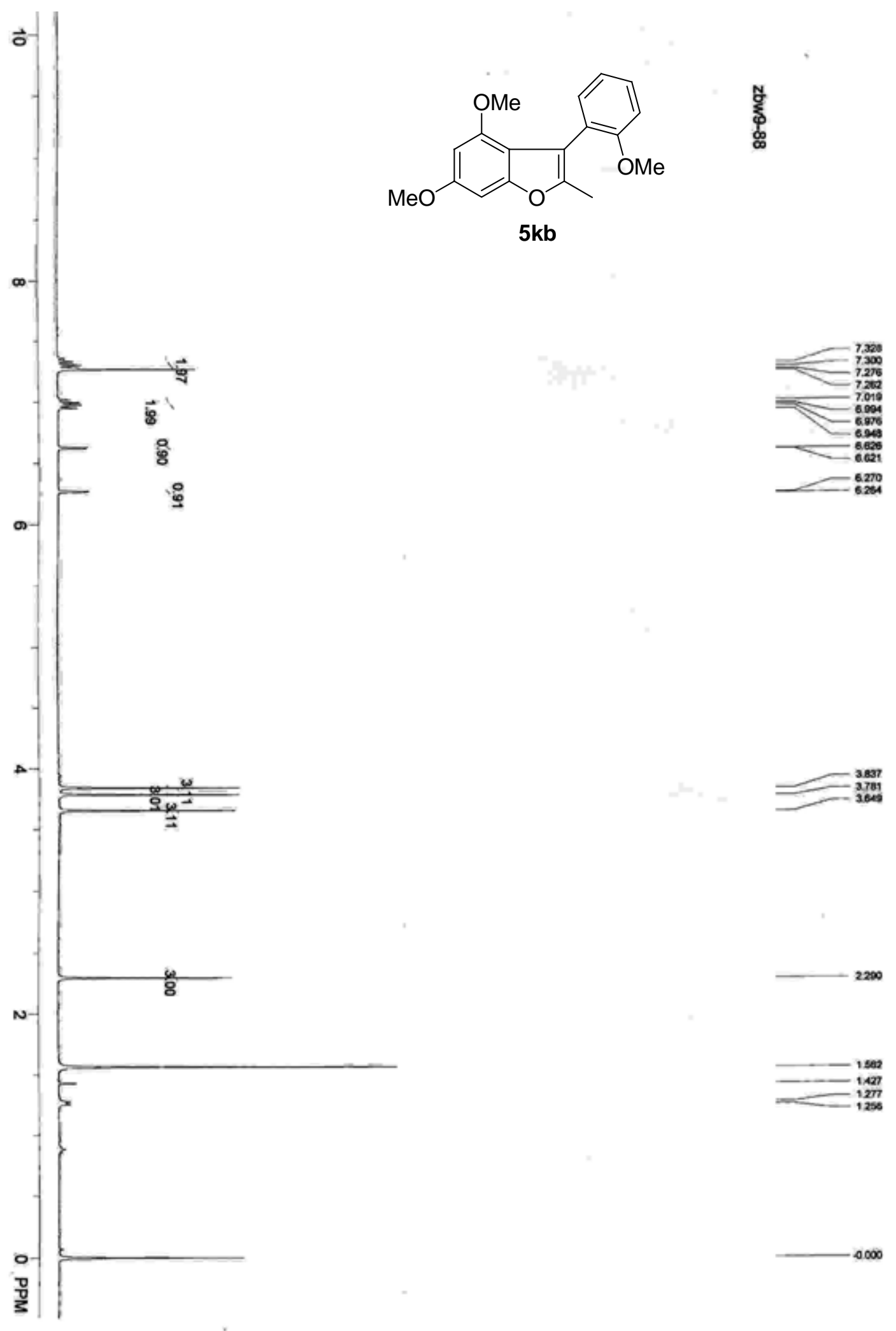




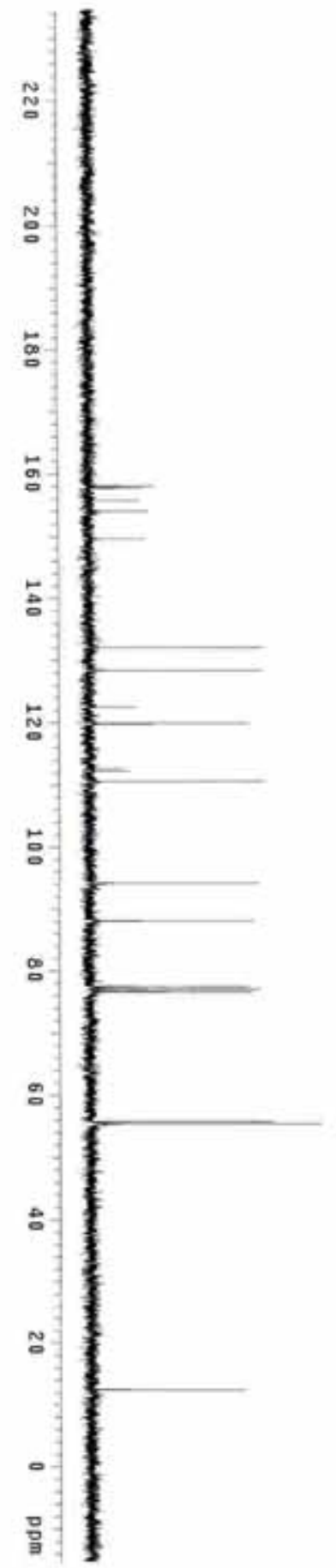<smiles></smiles>

$5 \mathrm{~kb}$

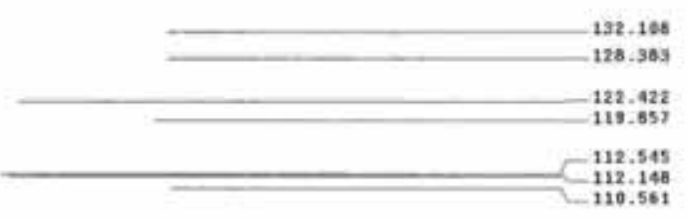

94. 135

so.029

-77.627

$-76.580$

$-55.674$

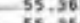

12.466 


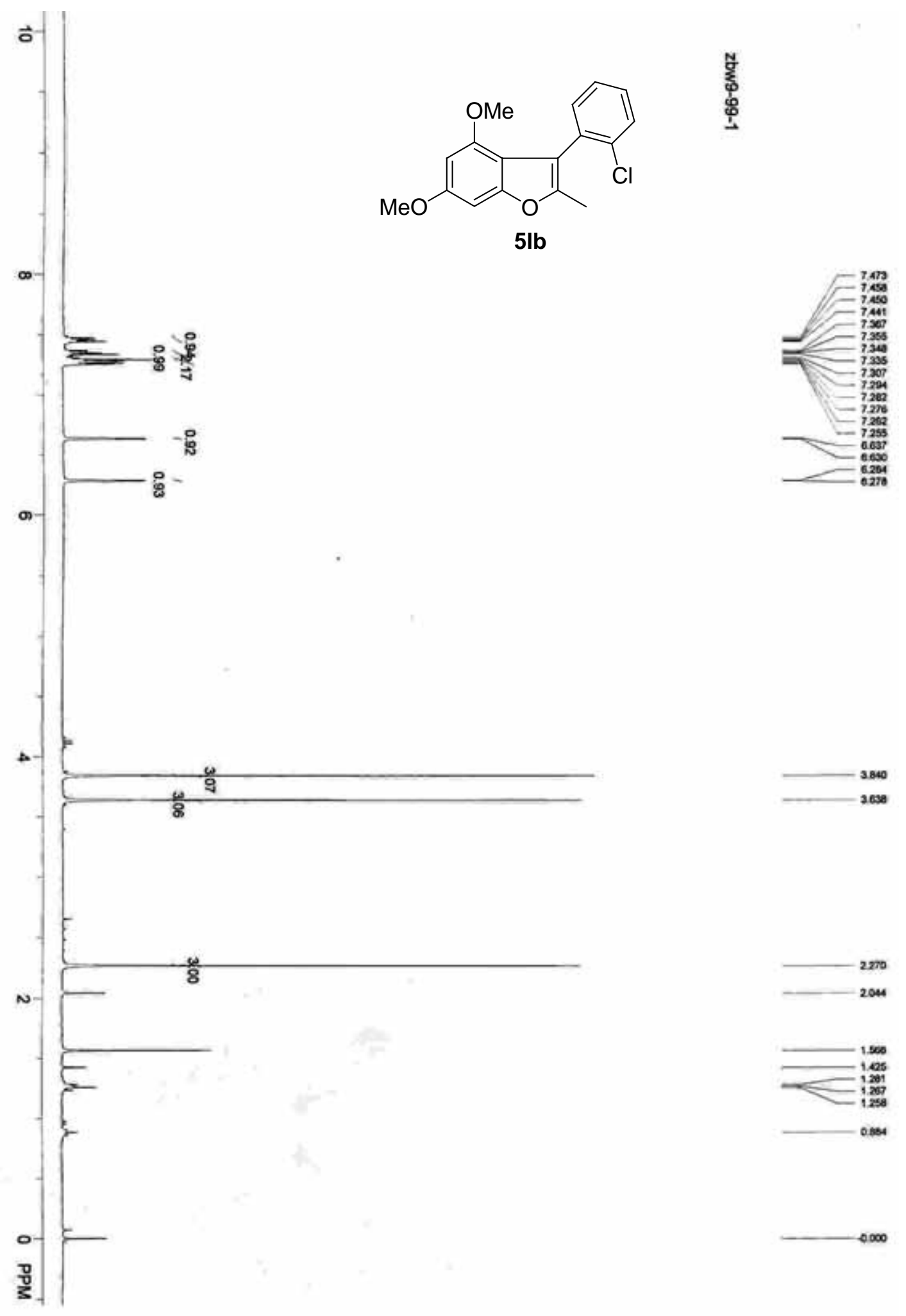



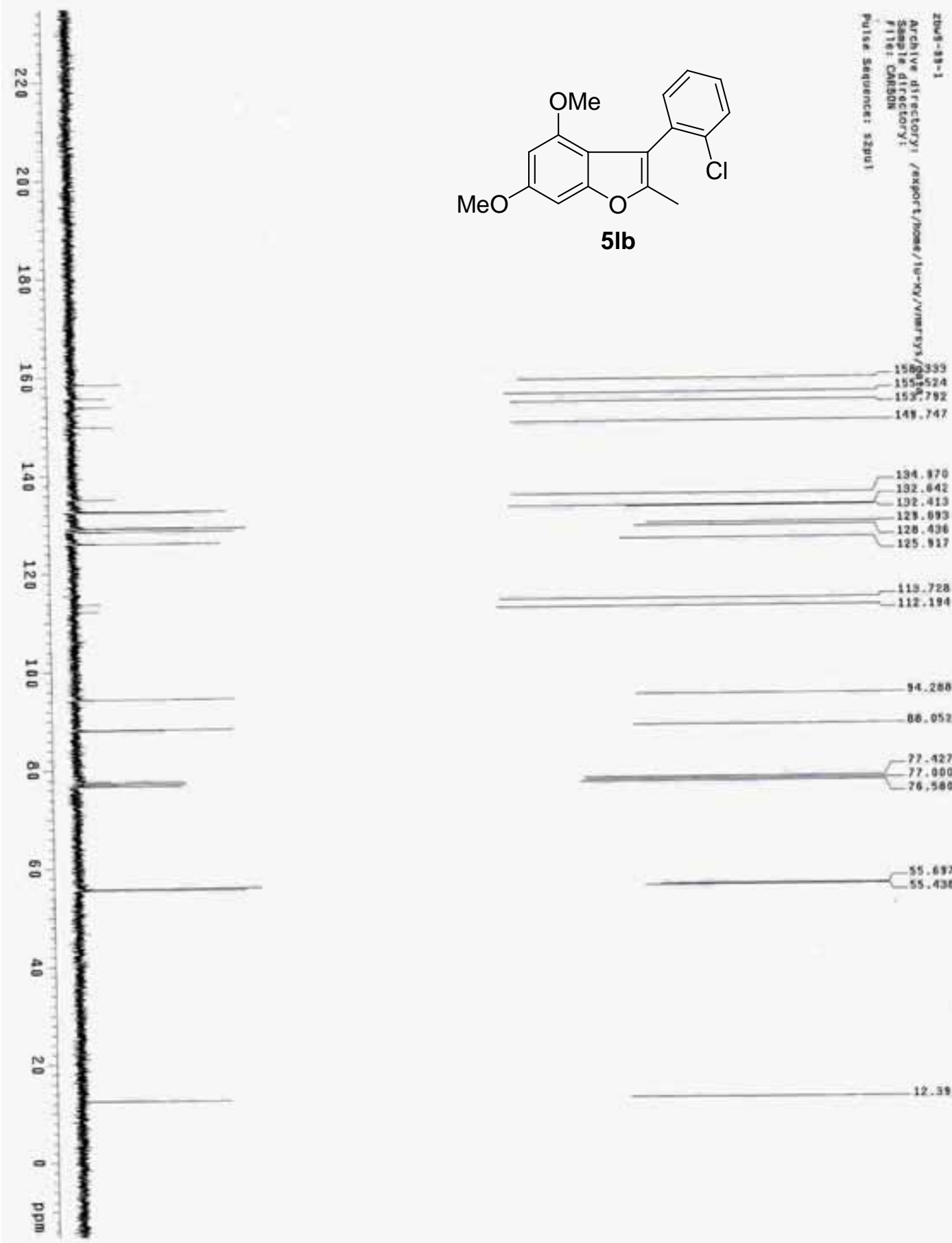

119.728
-112.199

.94 .258

-06.052

$-7,427$
-17.000

$-76.580$

$-55.67$

12.390 


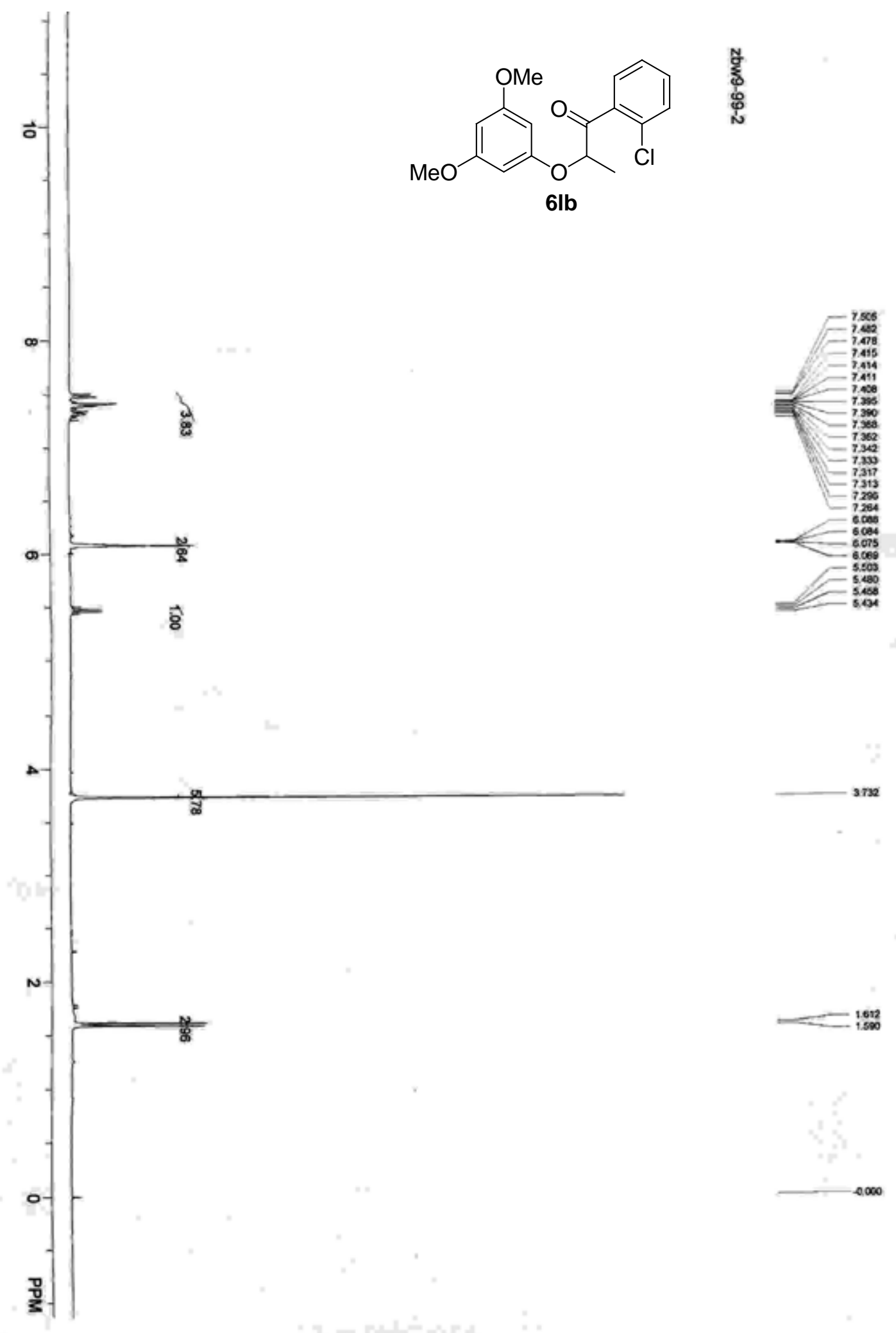



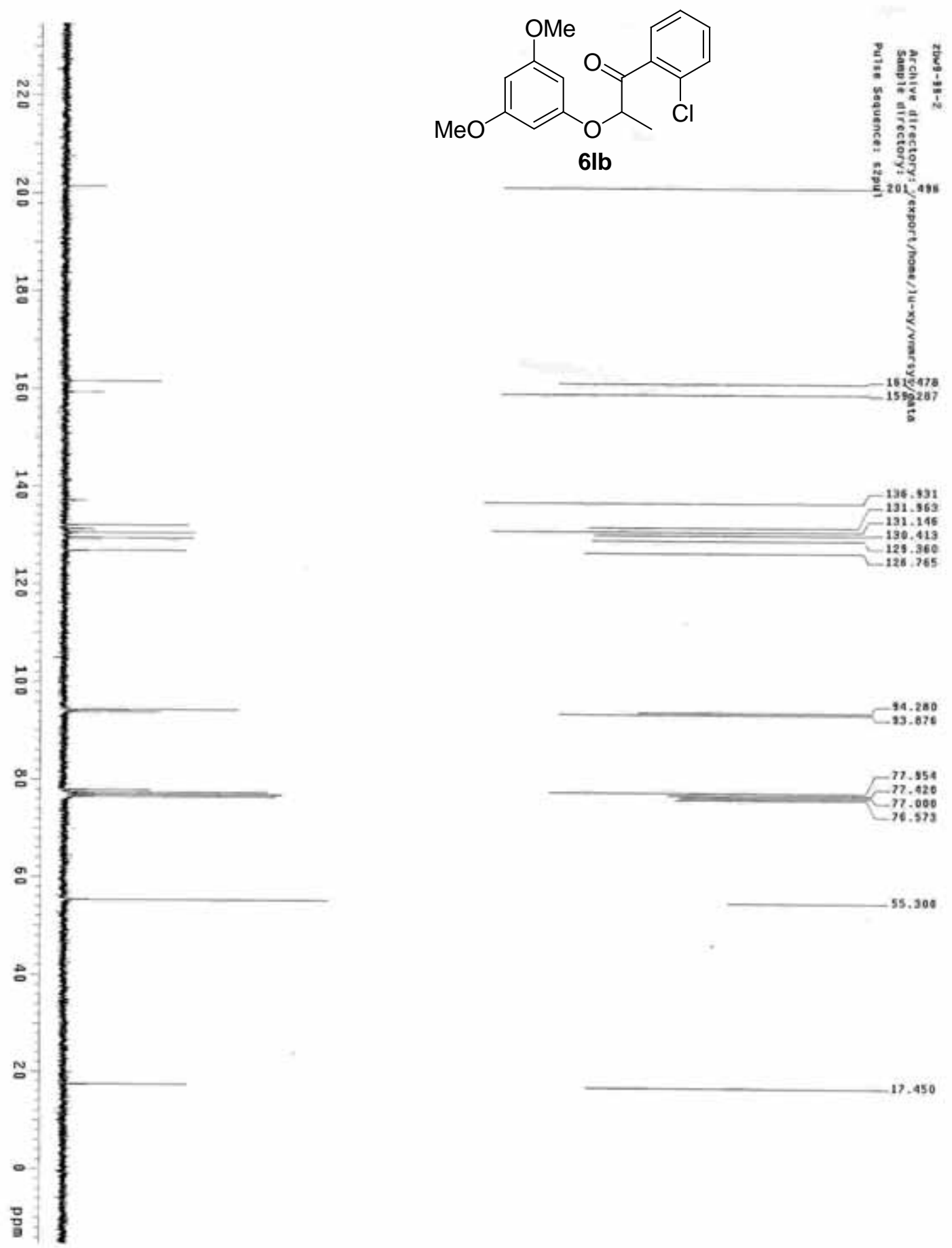

94.280
93.876

77.554
-77.420
-77.000

77.000
-76.573

55.300

$-17.450$ 